\title{
The WAy PHILOSOPHERS PRAY: HYMNS AS EXPERIENTIAL KNOWLEDGE IN EARLY MODERN EUROPE*
}

\author{
MARCo Piana (UNiVERSiTy OF TORONTO) \\ MATTEO SORANZO (MCGILL UNIVERSITY)
}

\begin{abstract}
Beginning with the work of Marsilio Ficino through the poems of Michele Marullo, Gianfrancesco Pico della Mirandola, Pierre Ronsard, Edmund Spenser and others, this essay discusses the revival and fortune of philosophical hymns in Quattrocento Italy and the diffusion of this genre in Early Modern Europe. In doing so, we will attempt at framing this phenomenon in the context of Early Modern religious pluralism and interpret it as an instance of experiential knowledge.
\end{abstract}

\section{Key Words}

Hymns, Neoplatonism, Religious Pluralism.

In common parlance as well as in standard histories of philosophy the language of prayer and the language of reason are ascribed to different, if not contrasting, domains. Scholars commonly distinguish between petitionary prayers and meditative prayers. The former entail a specific request addressed to a nonhuman entity such as a god, a planet or a personified abstract concept. The latter consist of the ritualized repetition of words meant to prepare the subject's soul to receive otherwise inaccessible truths. ${ }^{1}$ Neither of these acts and their defining languages, however, are generally associated with the form of knowledge expected to be found in philosophical texts. Ritual invocations, commands, direct

* This article builds on the research performed as part of the SSHRC-funded academic project "Self-Transformation in Early Modern Europe », directed by Matteo Soranzo.

1 GRegory D. Alles et al., "Prayer», in Religion Past and Present Online. doi: $<$ http://dx.doi.org/10.1163/1877-5888_rpp_COM_08151>. 
questions, lists of divine attributes and descriptions of the subject's grasp of things precluded to discursive knowledge would be out of place in an anthology of philosophical texts. Aesthetically pleasing or culturally interesting, the ceremonial phrases, theurgical operations and - to use the expression coined by Pierre Hadot - 'spiritual exercises' disseminated throughout the most representative texts of ancient philosophy are often dismissed as a product of the times, which the historian of philosophy is called to remove from what are conventionally thought to be philosophical problems. Convenient as it might be for didactic purposes, however, is this operation useful from a historical perspective?

At the core of today's selective approach to philosophical texts, one finds enduring assumptions concerning the forms of knowledge traditionally considered philosophical. After Descartes, a priori and propositional knowledge imposed themselves as suitable for a definition of philosophy extolling theory over practice and mind over body. Conversely, experiential knowledge, intuition and other forms of non-discursive thinking such as bodily experience, performance and rituals ended up being dismissed as inferior, unreliable or confined to other, non-philosophical domains of investigation. ${ }^{2}$ Western cultural history, however, gives evidence of a much more diversified scenario characterized by a dramatically broader notion of what may count as knowledge. Rituals and the performance of ceremonial prayers, for example, are widely documented in Plato and, most importantly, in some of his late antique interpreters such as Plotinus, Proclus, and Iamblichus. ${ }^{3}$ Somewhat unsurprisingly, however, histories of philosophy have the tendency to characterize these facets of Neoplatonism as 'sub-philosophical phenomena' and ascribe them to an 'underworld' responsible for the corruption of an otherwise rational philosophical tradition. ${ }^{4}$

Philosophers writing in the aftermath of Descartes generally dismissed philosophical prayers as unfitting for philosophical discourse and perceived

2 KeVIN SCHILBRAK, «Introduction; on the Use of Philosophy in the Study of Rituals », in KeVIN Schilbrak (ed.), Thinking Through Rituals: Philosophical Perspectives, Routledge, New York 2004, p. 1-30.

3 Recent scholarship has nevertheless started to inquire in this traditionally neglected facet of Neoplatonism. see, for instance, John M. Dillon, Andrei Timotin (eds.), Platonic Theories of Prayer, Brill, Leiden 2016 (Studies in Platonism, Neoplatonism, and the Platonic Tradition, 19); ANDREI Timotin, La prière dans la tradition platonicienne, de Plato à Proclus, Brepols, Turnhout 2017 (Recherches sur les rhétoriques religieuses, 22).

4 WOUter J. HANEGRAAFF, Esotericism and the Academy: Rejected Knowledge in Western Culture, Cambridge University Press, Cambridge 2012, p. 12-13. In his critique of dismissive treatments of Neoplatonic rituals, Hanegraaff is referring to JoHN M. Dillon's seminal work The Middle Platonists, 80 BC-AD 220, Cornell University Press, Ithaca 1977. This relatively old book, however, might not represent Dillon's current view on the subject. 
rituals as 'thoughtless acts'. ${ }^{5}$ As this essay will illustrate, however, the rationalist rebuttal of philosophical prayers was only one possible outcome of a number of possibilities available in Early Modern Europe. As they deployed their scholarly skills to investigate ancient documents, Renaissance interpreters of Plato like Marsilio Ficino (1433-1499), for example, paid close attention to the role experiential knowledge played in their sources. The arguments, doxologies, propositions and refutations found in Ficino's Platonic Theology, in this respect, are complementary to the rituals, prayers, dietary restrictions and regimented lifestyle discussed in the Three Books on Life - a text not commonly found in histories of philosophy. At the same time, humanistically trained scholars like Gianfrancesco Pico della Mirandola (1470-1533) perceived the recitation of prayers straying from Christian liturgical practice as deeply problematic, thus contributing to suppressing or confining this genre to non-philosophical domains such as antiquarianism or literature. The exclusion of prayer from philosophical discourse, as we contend, is thus a multifaceted phenomenon entangled with broader historical trends such as Renaissance humanism, the Protestant Reformation and Early Modern literary history. This essay will attempt to interpret this phenomenon in light of Kocku von Stuckrad's notions of Early Modern religious pluralism and, more specifically, this scholar's concept of experiential knowledge.

In a conversation with other historians of religions, von Stuckrad has recently challenged the dominant narrative of Europe as a homogeneously Christian continent headed toward secularization. Religious identities, in this scholar's perspective, are best understood as the result of a negotiation among different external (e.g. Christianity, Islam, Judaism) and internal (Neoplatonism, Hermeticism, Kabbalah) options. European culture, on the other hand, is approached as the site for a plurality of diverse, and often competing, ways of attaining knowledge (e.g. syllogistic reasoning, dialogue, contemplation), associated with different institutions of learning (e.g. universities, courts, monasteries) often in contrast with each other. Approaching religion as a set of discursive practices and communications, von Stuckrad has defined experiential knowledge as a claim to an absolute truth, which cannot be phrased in the usual language of reasoning but can only be announced to the reader by means of exhortations, commands, metaphors and symbols. In this perspective, tracing the history of experiential knowledge consists in observing the inclusion or exclusion of this discursive form in, or from the institutions of learning available in a given period. ${ }^{6}$

SCHILBRAK, « Introduction: on the Use of Philosophy », p. 1-2.

KOCKU VON STUCKRAD, Locations of Knowledge in Medieval and Early Modern Europe: Esoteric Discourse and Western Identities, Brill, Leiden 2010 (Brill's Studies in Intellectual History, 186), p. 7-24. VoN STUCKRAD has further refined this analytical framework in the first chapter of his The 
This essay will interpret philosophical prayers as instances of the aforementioned language of experiential knowledge. Rooted in ancient texts like the gradual initiation to the noetic contemplation of Beauty described by Diotima in Plato's Symposium, this language - as Sarah Rappe has thoroughly illustrated is also present in the numerous allusions to non-discursive thinking disseminated in the works of Plotinus, Proclus and Damascius. ${ }^{7}$ As we contend, the Quattrocento rediscovery of philosophical hymns brought about a revival of experiential knowledge in the context of the new and eclectic spirituality adopted by some Renaissance humanists. ${ }^{8}$ As they learned to approach and appreciate antiquity in its alterity, Early Modern authors found themselves entangled in a clash of symbolic paradigms in their search for significance. Hymn singing, in the form of meditative or petitionary prayer, offered a viable form of synthesis between non-Christian antiquity and Christian early modernity, which were perceived, at times, as potentially complementary, and at other times as diametrically opposed.

\section{Plato, Plotinus and Ficino's Prayers}

Marsilio Ficino's revival of Plato's philosophy is the starting point in the rediscovery of philosophical hymns mapped in this essay. Plato's works, of course, had been partially known throughout the Middle Ages, and genuinely Platonic themes, often mediated by Arabic commentators of Aristotle, had already made their way into European Universities and monastic schools. ${ }^{9}$ Moreover, a halo of sanctity largely dependent on Augustine and Boethius had long surrounded Plato and his teachings. Not only the erudite monks of the School of Chartres but also poets such as Dante and Petrarch had long acknowledged Plato's role in paving the way for Christian revelation. Limited access to original sources, a general lack of commentaries comparable to those accompanying Aristotle's works and, most importantly, a curriculum of learning

Scientification of Religion: An Historical Study of Discursive Change, 1800-2000, De Gruyter, BostonBerlin 2014. Although tested upon a corpus of relatively modern texts, von Stuckrad's discourse analysis, in our view, might have a great potential for analyzing other early modern 'entanglements' of philosophical and religious discourses such as those examined in this essay.

7 Sarah A. Rappe, Reading Neoplatonism: Non-Discursive Thinking in the Texts of Plotinus, Proclus, and Damascius, Cambridge University Press, Cambridge 2007, p. 20-21.

8 Matteo SoRAnzo, « Words of Conversion: Poetry and Religious Identity in Early Modern Italy ", Journal of Religion in Europe, 6 (2013), p. 229-262; ID., « A New Look at Spirituality: Knowledge and Transformation in Early Modern Italy », Journal of Religion in Europe, 8 (2015), p. 185-209.

9 StePhen Gersh, «The Medieval Legacy from Ancient Platonism », in STEPHEN Gersh et al. (eds.), The Platonic tradition in the Middle Ages: A Doxographic Approach, De Gruyter, Berlin 2002, p. 3-30; James Hankins, "Plato in the Middle Ages ", in Joseph Strayer, William Chester Jordan (ed.), Dictionary of the Middle Ages, vol. IX, Scribner and Sons, New York 1987, p. 694-704. 
founded on Scholasticism had all contributed to preclude Western European readers from Plato's dialogues. The failed attempt to reunite the Eastern and Western Churches in 1439, the fall of Constantinople in 1453, and the enduring migration of Byzantine scholars and books to the Italian peninsula, are among the factors that paved the way for Ficino's intellectual enterprise and its manifold intellectual ramifications. ${ }^{10}$

For readers accustomed to the conventional idea of philosophy as the rational investigation of universal truths, the new chapter started by Ficino and his followers might seem an oddity. The philosopher from Figline was a selfproclaimed 'doctor of the soul' inclined to ecstatic experiences and animated by a quasi-prophetic zeal to transform the souls of scholars and political leaders of the time. He was loyal to a Hellenistic idea of philosophy that, as Pierre Hadot influentially argued, used to be conceived as a way of life rather than a purely theoretical pursuit. ${ }^{11}$ Like other Renaissance scholars, Ficino rediscovered this ancient idea of what counts as philosophy in contrast with, and often in response to, the research questions and established curricula of readings characterizing traditional institutions of learning such as, most importantly, universities. ${ }^{12}$ Free from academic constraints, Ficino became immersed in the work of late antique philosophers such as Plotinus, Proclus, Iamblichus and - much like these authors before him - non-Christian Revelations such as the Corpus Hermeticum, the Orphica, and the Oracula Chaldaica. In line with his late antique predecessors, Ficino and his followers drew from Plato's dialogues the coordinates of a mystical path toward spiritual transformation and reunion with the metaphysical One. This broader notion of philosophy diverged from the still dominant view of this discipline as an ancilla theologiae useful for, but subordinate to, the pursuit of Christian faith. The factors that make Ficino somewhat unusual as a philosopher, however, are at the origin of his influence on spirituality, magic, literature and the visual arts, and at the forefront of his relatively recent scholarly revival. ${ }^{13}$

An important aspect of Ficino's legacy is his impact on religious practices and, more specifically, on prayer. Indeed, scholars have recently analyzed Ficino's theology in the context of fifteenth-century religious history. Christopher Celenza has persuasively proposed to approach Ficino's distinctive philosophical persona in terms of Garth Fowden's notion of Late Ancient 'holy man,' thus emphasizing the Florentine's conception of philosophy as a form of spiritual

10 JAmEs HANKINS, Plato in the Italian Renaissance, Brill, Leiden 1990 (Columbia Studies in the Classical Tradition, 17), p. 300-301.

11 PIERRE HADOT, Philosophy as a Way of Life: Spiritual Exercises from Socrates to Foucault, trans. ARNOLD IRA DAVIDSON, Blackwell, Oxford 1995, p. 33, 271-272.

12 Christopher S. Celenza, "What Counted as Philosophy in the Italian Renaissance ", Critical Inquiry, 39/2 (2013), p. 367-401.

13 Christopher S. Celenza, «The Platonic Revival », in JAmes Hankins (ed.), The Cambridge Companion to Renaissance Philosophy, Cambridge University Press, Cambridge 2007, p. 84-86. 
practice. ${ }^{14}$ James Hankins, moreover, has persuasively interpreted Ficino's ecumenical acceptance of multiple religious traditions as a response to established theological discourses. Nominalism, Hankins has argued, entailed a sharp divisions between reason and faith. Thomism, on the other hand, attempted to understand God with the instruments of logic. Ficino's 'theological coherentism,' as Hankins has called it, was meant to be an alternative in the period of fluidity that preceded the Reformation and the Council of Trent. ${ }^{15}$ Wouter J. Hanegraaff has persuasively interpreted Ficino's religious views in the context of Western Esotericism. Whether one takes this category as a form of thought centered on recurrent themes such as the existence of a living nature and the agreement among different religious traditions or, rather, as a narrative centered on the belief in a perennial truth linking Antiquity and Christianity, Ficino has proven to be a central figure in defining this facet of European religious history. ${ }^{16}$ Brian Copenhaver and, most importantly, Denis Robichaud, moreover, have provided essential insights into the sources and philosophical premises of Ficino's adoption of theurgical practices and prayers ${ }^{17}$ None of these scholars, however, have focused specifically on the features of Ficino's hymns or the influence they had on later authors of philosophical prayers. This omission is precisely what this essay seeks to address. ${ }^{18}$

This neglect, in our view, originates from a vexata quaestio in the scholarship on Ficino. Indeed, scholars have often focused on the role played by invocations, hymn singing, and ceremonies in Ficino's works, and have acknowledged the centrality of rituals in the Florentine's way of practicing philosophy. In his seminal study on Ficino's spiritual and demonic magic, Daniel P. Walker dedicated a long and inspiring chapter to the function Ficino attributed to theurgy, that is, the evocation of natural powers and supernatural entities in the context of a philosophical ritual. Walker concluded that Ficino did perform rituals involving prayers, invocations, singing, and liturgical hangings (i.e.

14 Christopher S. Celenza, « Late Antiquity and Florentine Platonism: the 'Post-Plotinian' Ficino » in Michael J. B. Allen et al. (ed.), Marsilio Ficino: His Theology, His Philosophy, His Legacy, Brill, Leiden 2002 (Brill's Studies in Intellectual History, 108), p. 82-83.

15 James Hankins, « Marsilio Ficino and the Religion of the Philosophers », Rinascimento, 48 (2008), p. 101-121.

16 HanegraAfF, Esotericism and the Academy, p. 41-53.

17 Brian P. Copenhaver, « Renaissance Magic and Neoplatonic Philosophy: Ennead 4.3-5 in Ficino's De vita coelitus comparanda », in GIAN CARLo GARFAGNINI (ed.), Marsilio Ficino e il ritorno di Platone, Leo S. Olschki, Florence 1986 (Istituto nazionale di studi sul Rinascimento. Studi e testi, 15), vol. II, p. 351-369; Denis Robichaud, «Ficino on Force, Magic and Prayers. Neoplatonic and Hermetic Influences in Ficino's Three Books on Life ", Renaissance Quarterly, 70/1 (2017), p. 44-87.

18 For a short overview of philosophical hymns and their history, see MATTEO SoRANzo, «Les hymnes platoniciens et leur rôle dans la spiritualité prémoderne », in EVA KuSHNER (ed.), L'époque de la Renaissance (1400-1600), t. II: La nouvelle culture (1480-1520), Benjamins, Amsterdam 2017, p. 29-37. 
banners etc.), the function of which was mainly to inspire the transformation of the officiant, rather than to have a practical effect on things, people, and events. Also, Walker influentially demonstrated that Ficino distinguished between a kind of magic that acts upon the spiritus mundi - an intermediate substance linking Matter and the World Soul - and another, more dangerous kind, which sought to act upon reality through the intervention of demons. ${ }^{19}$ Frances A. Yates, in conversation with Walker, further explored Ficino's views on prayers and invocations by examining the relationship between the commentary on Plotinus' Enneads and the Three Books on Life, a thorny philological problem that was first acknowledged by Kristeller, and which Yates tried to resolve by interpreting Ficino's conception of prayer as a facet of the author's enthusiastic revival of Hermetic magic. ${ }^{20}$ While still persuasive and inspiring, however, these scholarly works only tangentially touched upon the actual form, context, and content of Ficino's prayers. Also, these studies tend to come to terms with the obvious strangeness of Ficino's revival of what is, ultimately, a non-Christian spiritual practice by confining it to the 'tainted' domain of magic, rather than investigating the spiritual needs Ficino's prayers might have meant to fulfill. Either way, by their reductio ad magiam, so to speak, Walker and Yates lost sight of an interesting aspect of Ficino's legacy that - as the long-lasting legacy of philosophical hymns demonstrates - goes beyond the specific domain of magic.

Contrary to what Walker and Yates argued, Ficino's views on prayer and the role invocations play in the life of philosophers are central aspects of his interpretation of Plato and Plotinus. Theurgical prayers, more precisely, are not confined to the domain of what Nicolas Weill-Parot has defined as 'addressative magic' and are only loosely connected with Ficino's interest in the Corpus Hermeticum. ${ }^{21}$ More precisely, Copenhaver has demonstrated that the third section of Ficino's Three Books on Life is best understood as a commentary on Plotinus' Enneads concerning the effects of prayers on nature, rather than an expression of hermetic magic. More recently, Robichaud has conducted an investigation of these texts and their sources, together with a meticulous examination of the marginal annotations Ficino left on his copies of Plotinus' text. In doing so, Robichaud has demonstrated that Ficino's interest in prayer was actually informed by Proclus, Iamblichus and Al-Kindi and not so much - as Yates argued - by the hermetic Asclepius. Robichaud, moreover, has shown that Ficino's

19 DANiel P. WALKER, Spiritual and Demonic Magic from Ficino to Campanella, University of Notre Dame Press, Notre Dame 1975, p. 30-59.

20 Frances A. Yates, Giordano Bruno and the Hermetic Tradition, University of Chicago Press, Chicago 1964, p. 62-84.

21 Nicholas Weill-Parot, «Astral Magic and Intellectual Changes (Twelfth- Fifteenth Centuries). Astrological Images and the Concept of Addressative Magic », in JAN N. BREMMER, JAN R. VeENSTRA, (eds.), The Metamorphosis of Magic from Late Antiquity to the Early Modern Period, Peeters, Louvain 2001 (Groningen Studies in Cultural Change, 1), p. 167-188. 
hermeneutical efforts stemmed from an apparent contradiction in Plotinus' conception of prayer, which at first sight might appear to be at odds with the philosopher's conception of the One as eternal, immovable and, thus, impervious to human requests. In fact, Ficino grafted onto his interpretation of Plotinus later theories of universal sympathy such as those found in Al-Kindi, thus producing a coherent view of prayer as a form of verbal meditation capable of making the officiant's soul resonate with the immovable One, rather than forcing the One to listen to a verbal utterance confined to a lower hypostasis. ${ }^{22}$

Alongside the specific problems addressed in these studies, we suggest that the long-lasting difficulties in grappling with Ficino's conception of prayer have deeper roots. Although William James influentially called prayer «the very essence and soul of religion ", scholars have unanimously acknowledged the difficulty of understanding what prayers ultimately are. ${ }^{23}$ Depending on whether one investigates the content, context, form or ritual practice of prayers, as Roy Hammerling has recently contended, research can produce multiple, and at times conflicting, results. ${ }^{24}$ Also, and most pertinent to the case of Ficino, prayers constitute a challenge for conventional boundaries between philosophy, theology, literature, and culture in general. Following in the footsteps of Jonathan Z. Smith, who first questioned the legitimacy of traditional distinctions between religion and other cultural activities, Hans G. Kippenberg and von Stuckrad have recently proposed to approach religious texts as instances of discursive practices taking place in a pluralistic context, rather than the documents of an actual experience or a distinct state of the mind. ${ }^{25}$ In light of these methodological guidelines, we contend that Ficino contributed to the revival of an ancient form of experiential knowledge obtainable by means of the performance of hymns. Rather than magical incantations, Ficino and his followers perceived the recitation of philosophical hymns to be part of a meditative practice, the function of which was to awaken and prepare the soul to experience an absolute, non-discursive form of knowledge. ${ }^{26}$

22 RoBichaud, « Ficino on Force, Magic and Prayers ».

23 William James, The Varieties of Religious Experience: A Study in Human Nature, Modern Library, New York 1936, p. 337.

24 Roy HAMmerling, "Introduction », in Roy HAMmerling (ed.), A History of Prayer: The First to the Fifteenth Century, Medieval Academy of America, Cambridge 2009, p. 3-4.

25 HANS G. KIPPENBERG, KocKU VON STUCKRAD, Einführung in die Religionswissenschaft, Beck, Munich 2003, p. 136-46; VON STUCKRAD, «Discursive Study of Religion: from State of the Mind to Communication and Action ", Method and Theory in the Study of Religion, 15/3 (2003), p. 255-271.

26 In this sense, Ficino's views on prayers might be interpreted as an instance of the same expanded conception of philosophy he deployed in grappling with Plotinus' language of conversion. For a discussion of this theme, see Denis Robichaud, MatTeO SoRAnZo, «Philosophical or Religious Conversion? Marsilio Ficino, Plotinus' Enneads and Neoplatonic epistrophe ", in Simona Marchesini (ed.), Simple Twists of Faith, Changing Beliefs, Changing Faiths: People and Places, Alteritas, Verona 2017, p. 135-166. 


\section{Ficino's Hymns and Spiritual Exercises}

Grounded in his interpretative work on Plotinus' Enneads, Ficino's interest in ancient hymns was guided by more pressing needs than the satisfaction of scholarly curiosity. Browsing through Ficino's letters is sufficient to reveal the crucial role the performance of meditative prayers played in his philosophical project. Every day, one learns from Ficino's letter to Bernardo Rucellai, the philosopher would ask God for clarity of mind and good will by means of a long prayer (oratio), whose words are generously shared with his friend. ${ }^{27}$ In a letter addressed to Cosimo de' Medici on September 8, 1462, the Florentine philosopher addresses his patron Cosimo as pater patriae and describes in detail the performance of a hymn taken from the Orphic Hymns, a collection of prayers traditionally attributed to the mythical poet Orpheus, which fifteenth-century humanists had recently brought to light. ${ }^{28}$ Ficino's performance of Orpheus' hymn to the Cosmos is presented not only as an encomiastic poem but also as a ritual having tangible effects on both the philosopher's mind and his destiny, thus determining Cosimo's generosity toward the Florentine philosopher. ${ }^{29}$ In a letter to his friend and follower Giovanni Cavalcanti, Ficino explains the positive effects of hymn-singing as an antidote against melancholy. By addressing hymns of recantation to Saturn, the planet deemed responsible for triggering black bile and a state of depression, Ficino and his interlocutor believe that the soul can be turned toward God and away from the lesser elements afflicting the body. ${ }^{30}$ As can be learned from these letters, Ficino's hymns are to be taken as an attempt at rediscovering ancient hymns as religious experiences and spiritual exercises, the purpose of which - in line with Plato's philosophy - is turning the human soul away from the multiplicity of the bodily prison toward her archetypical counterpart, which is thought to reside in the intelligible world.

This practice may seem strange to a modern reader. However, Ficino's use of hymns as performative and meditative prayers is rooted in the philosopher's exegetical context. Along with the collection of hymns attributed to the mythical poet Orpheus, which had been widely circulating in manuscript form since 1424 until their first printed edition in 1501, as well as Plotinus' Enneads, Ficino's views on the nature of prayer were also inspired by Proclus (412-485 AD). Besides authoring treatises and commentaries on Plato, Proclus also distinguished

27 Marsilio Ficino, The Letters of Marsilio Ficino, Shepeard-Walwin, London 2018, vol. I.116, p. 148151.

28 On the rediscovery and editorial history of the Orphic hymns, see DANIEL. P. WALKER, « Orpheus the Theologian and Renaissance Platonists ", Journal of the Warburg and Courtauld Institutes, 16/12 (1953), p. 103-104.

29 ANGEla Voss, Marsilio Ficino, North Atlantic Books, Berkeley 2006, p. 59-60.

30 Voss, Marsilio Ficino, p. 65. 
himself as a composer of hymns. ${ }^{31}$ Proclus thought that in his dialogues Phaedrus and Parmenides Plato himself had envisioned philosophy as a form of hymnsinging, by which he meant a form of meditative prayer, the goal of which is turning the human soul toward the cosmic intelligences. ${ }^{32}$ Proclus' views on the performance of hymns were closely related with his general conceptions regarding the position of human beings in the cosmos. More optimistic interpreters of Plato, such as Plotinus, had argued that human beings could aspire to lift their minds to the sphere of Intellect (nous) without the need of intermediaries. Proclus, on the contrary, argued that a wide gap existed between the human soul and the sphere of the Intellect, so that humans could aspire to reunite themselves with the One (henosis) only by means of apposite ceremonies and invocations addressed to higher gods (theurgia). ${ }^{33}$ And since the will of the gods, according to Neoplatonic ethics, cannot be moved by human prayers, Proclus' hymns were not petitions but meditations, by which the soul can convert (epistrophe) away from the material world and return to its heavenly homeland. ${ }^{34}$ For Proclus, and consequently for Ficino, praying was thus a central exercise in an authentic philosophical life, and the hymn was the archetypal form of this spiritual practice.

Rooted in Proclus' writings, Ficino's revival of ancient hymns in a dominantly Christian context constituted a bold and, to a certain extent, unacceptable, innovation. Indeed, during the Middle Ages a small selection of Orpheus' hymns had not only been available, but were also the object of theological and historical speculations. Early Church Fathers had managed to present Orpheus as a follower of Moses in Egypt, as well as a man whose descent into the underworld prefigured Christ's death and resurrection, and whose works had a grasp on true faith. $^{35}$ Medieval readers, moreover, would have been familiar with the Neoplatonic hymns found in Boethius' Consolation of Philosophy, and the central role these prayers play in Lady Philosophy's attempt at rescuing her devotee's soul from the spiritual and physical chains of prison and exile. Once they were rediscovered in the fifteenth century, however, the hymns of Orpheus, Proclus, Homer, and Callimachus would have been at odds with dominant views concerning the scope and purpose of prayers. According to Thomas Aquinas, invocations addressed to deities other than God, besides violating the first commandment, were incompatible with Christian prayer. ${ }^{36}$ By praying, Thomas contended, humans should strive to actively cooperate with the unfolding of an

\footnotetext{
WALKER, « Orpheus the Theologian and Renaissance Platonist », p. 104-108. ROBERT VAN DEN BERG, Proclus' Hymns: Essays, Translations, Commentary, Brill, Leiden 2001, p. 24-26. 
otherwise immutable divine plan; in doing so, therefore, only God should be the petitioner's addressee. ${ }^{37}$ Secondly, and in a way that intentionally evoked the works of Augustine, Aquinas claimed that there was only limited space for innovation in the formulation of prayers, which should always be modeled on Scriptures, and more precisely on the petitions found in the Lord's Prayer and Christ's Prayer in the Garden of Gethsemane. ${ }^{38}$ The adoption of pre-Christian hymns - which distinctively open with invocations addressed to a god that was conceptualized as the personification of a natural phenomenon or abstract philosophical concept - was thus in conflict with dominant views on prayer.

As Copenhaver has persuasively demonstrated, in De Vita Ficino was well aware of Aquinas' views on prayer. ${ }^{39}$ As far as hymns are concerned, however, one should consider that he lived in a period of relative openness to liturgical innovations. Based on a better knowledge of classical Latin, and in response to the ongoing reform of the Liturgical Calendar, for example, Renaissance humanists often denounced the linguistic awkwardness and metrical clumsiness of traditional Christian hymns. ${ }^{40}$ The need for new collections of rhetorically elaborate prayers, which explored Christian spirituality through classical imagery and meters, resulted in the composition of numerous collections of prayers such as Giovanni Pontano's De Laudibus Divinis and, even more systematically, Ludovico Lazzarelli's Fasti Christianae Religionis or Baptista Mantuanus' De Sacris Diebus. ${ }^{41}$ These experiments culminated during the papacy of Pope Leo X, a descendant of Cosimo and Lorenzo de Medici, who entrusted Zaccaria Ferreri (1479-1523) with the composition of a new, humanistically crafted Hymnal, which was printed posthumously in 1525 during the papacy of Clement VII. ${ }^{42}$ During this short, yet incredibly prolific, period brusquely interrupted by the rise of the Lutheran schism and the subsequent Catholic response, therefore, Christian liturgy witnessed a series of attempted innovations and reforms, which the Council of Trent irremediably rejected. ${ }^{43}$ Besides being closely related to a context open to liturgical experimentation, Ficino's adoption

37 CoRey Barnes, "Thomas Aquinas on Christ's Prayer », in ed. HAMmerling, A History of Prayer, p. $325-326$.

38 Ibid., p. 329-334.

39 BRIAN P. COPENHAVER, «Scholastic Philosophy and Renaissance Magic in the De vita of Marsilio Ficino ", Renaissance Quarterly, 37/4 (1984), p. 523-554.

40 AnN Moss, «Latin Liturgical Hymns », Humanistica Lovaniensia: Journal of Neo-Latin Studies, 40 (1991), p. 73-111,75-79.

41 Isabelle Pantin, La poésie du ciel en France dans la seconde moitié du seizième siècle, Dròz, Genève 1995 (Travaux d'humanisme et Renaissance, 297), p. 245-249; Moss, « Latin Liturgical Hymns », p. 7987.

42 Moss, « Latin Liturgical Hymns », p. 82-83.

43 GIORGIO CARAVALE, Forbidden Prayer: Church Censorship and Devotional Literature in Renaissance Italy, Ashgate, Burlington 2011, p. 225-244. 
of pre-Christian hymns as instruments of meditation might also stem from the type of prayer on which he focused.

Differently from Aquinas, Ficino intentionally focused on meditative, rather than petitionary, prayers. In Three Books on Life, for instance, Ficino discussed a number of practices by which men of learning can realign their souls with the heavens by means of acts of contemplation, the ultimate goal of which is to prepare the operator's body and soul to achieve communion with God. ${ }^{44}$ Thus, hymns and prayers are carefully distinguished from incantations (cantiones), by which Ficino meant petitions to alternative intelligences that some could call to act directly, and thus blasphemously, upon things. ${ }^{45}$ Whether these restrictions, as Walker argued, stemmed from Ficino's attempted apology of his magic or - as Robichaud has clearly demonstrated - from his Neoplatonic sources, it should be taken into account that meditative prayers in general are more open to innovations than other types of prayer ${ }^{46}$ Psychologists of religion, in particular, have often emphasized how meditative prayers are characterized by a distinctive combination of methodological rigor and spontaneity. Open to innovation and intended to recreate the presence of God in the subject's soul, meditative prayers are marked by a lack of uniformity found, for instance, in the more formulaic and standardized language that members of a priestly class impose upon ritualistic prayers. ${ }^{47}$ Once adopted as a form of meditation, therefore, the theurgical hymns found or mentioned in pre-Christian sources could be perceived as spiritual exercises perfectly compatible with a Christian outlook that was open, especially during the late fifteenth century, to a relative degree of religious inclusivism. ${ }^{48}$

\section{Early Success of Hymns: The Case of Michele Marullo Tarcaniota}

Although short-lived and in many respects unique, Ficino's context witnessed a spectacular revival of theurgical hymns as a form of meditative prayer. Independently from Ficino, but in response to very similar late ancient sources, Greek émigré and controversial philosopher Plethon (1355-1454) had already advocated a similar adoption of hymn-singing as a meditative practice intended to mold the imagination of the subject to receive its divine counterpart, thus triggering a process of spiritual transformation. ${ }^{49}$ In 1486 , at the time of his failed

44 Marsilio Ficino, Three Books of Life, ed. Karol Kaske, John R. CLARK, Medieval \& Renaissance Texts \& Studies, Tempe 1994, p. 355-363; WALKER, Spiritual and Demonic Magic, p. 149.

45 FICINo, Three Books of Life, p. 307, 355; WALKER, Spiritual and Demonic Magic, p. 44.

46 Allan H. Cole, "Prayer », in David Adams Leeming et al. (eds.), Encyclopedia of Psychology and Religion, Blanton Peale, New York 2009, vol. I, p. 1372.

47 Michael Argyle, Psychology and Religion: An Introduction, Routledge, New York 2000, p. 95-96.

48 For an overview, see MATTEO SORANZO, « Concordance et différence religieuse », in KuSHNER (ed.), L'époque de la Renaissance (1400-1600), p. 7-19.

49 WALKER, Spiritual and Demonic Magic, p. 61. 
attempt to bring forth a project of theological reform in front of a group of doctors gathered in Rome during the papacy of Innocent VIII, Giovanni Pico della Mirandola planned to dedicate part of his nine hundred conclusions to Orphic Hymns with the declared intention of stimulating the minds of contemplative souls..$^{50}$ The subjective and transformative virtues of hymn singing, moreover, played a central role in Lazzarelli's Crater Hermetis - a dialogue set at the court of the King of Naples in which the listeners' minds are progressively transformed and made suitable to receive the author's secret knowledge. ${ }^{51}$ The author that best exemplifies the literary offspring of this influential moment in Early Modern spirituality, however, is Michele Marullo Tarcaniota (1458-1500), a Greek émigré and the author of a collection of twenty hymns entitled Natural Hymns (Hymni Naturales). The collection was finalized in Ficino's Florence and first printed on November 26, $1497 . .^{52}$

From its division into four books to the subject of each individual text, Marullo's hymns constitute a long spiritual exercise based on Ficino's particular form of Neoplatonism. The structure of the collection, for example, mirrors Ficino's well-known commentary on Plato's Symposium, which explains that the light of the eternal One radiates through the medium of four hypostases, which are called respectively Intellect or Angelic Mind, World Soul, Nature, and the Elemental Forms or Matter. ${ }^{53}$ While acknowledging Ficino's impact on Marullo's collection, Donatella Coppini has argued that, by situating a tragic hymn to alldevouring Earth at the end of his collection, Marullo would have poetically challenged Ficino's philosophical system based on the authority of Lucretius' De Rerum Natura..$^{54}$ Charles Fantazzi, on the other hand, has recently contended that Ficino's cosmology - together with those found in Proclus, Orpheus, and other late antique sources - resides at the very core of the Natural Hymns, which occasionally incorporate concepts and images borrowed from Lucretius without endorsing the pessimism of the Roman Epicurean. ${ }^{55}$ As Valery Rees has recently argued, however, one has to acknowledge that the macro-text of Marullo's collection is modeled on a hierarchical organization of Neoplatonic hypostases outlined in Ficino's works. Consistent with Ficino's metaphysical hierarchy, the first book is devoted to God's intellectual manifestations at the level of Intellect,

50 FRANCES A. YATES, The Occult Philosophy in the Elizabethan Age, Routledge, London 1979, p. 20-22.

51 Matteo Soranzo, «A New Look at Spirituality », p. 185-209. In addressing Lazzarelli, this article builds on the work of Claudio Moreschini and Wouter J. Hanegraaff.

52 This incunable comprises Marullo's epigram and natural hymns and was printed by the Societas Colubris in Florence.

53 Marsilio Ficino, Commentary on Plato's Symposium, ed. Jayne Sears Reynolds, Spring, Dallas 1985, p. 47.

54 Marullus, Inni naturali, ed. Donatella Coppini, Le Lettere, Florence 1995 (Il nuovo melograno, 21), p. 11, 228, 263.

55 Marullus, Poems, ed. Charles Fantazzi, Harvard University Press, Cambridge 2012, XIII. 
which articulates into the twofold triads of Jupiter, Pallas, Love, and Angels, Eternity, and Bacchus. As it moves onto the reason-principles residing in the World Soul, the second book comprises prayers addressed to Pan, Heaven, Stars, Saturn, Jupiter, Mars, Mercury, and Venus. The third book, which corresponds to the rational seeds inhabiting Nature, includes prayers addressed to the Sun and the Moon, which lead the reader to the body of the world and its corresponding elemental forms chanted in the hymns to Aether, Jupiter, Juno, Ocean, and Earth, which are conveniently placed in the fourth and final book. ${ }^{56}$

Despite their conspicuous adaptation of Neoplatonic themes, it might seem unusual to approach Marullo's Natural Hymns as philosophical texts. If a claim to knowledge is to be found in this text, it is one grounded in the subject's experience of spiritual transformation, rather than in more conventionally philosophical discursive practices such as syllogistic arguments or propositional knowledge. Modern readers might dismiss Marullo's prayers as literary fictions or 'thoughtless acts'. Once examined in its context, however, the collection displays the features of a spiritual exercise in Neoplatonic meditation. In line with the Stoic tradition of apatheia, Natural Hymns stages a poetic persona progressively detached from the inexorable laws of nature who experiences a specific state of consciousness, which has the features of what Hadot described as "view from above $»{ }^{57}$ Enclosed within the collection's Neoplatonic structure, Marullo narrates the experience of his own epistrophe, which - as for Proclus - is the result of the twenty meditative prayers found in his collection.

A representative instance of language of experiential knowledge is the final hymn to all-devouring Earth. This text is better understood as the result of the transformation described in the collection as a whole, rather than an allusion to Lucretius' tragic view of nature often emphasized by scholars. In a way that recalls Proclus' hymn-singing philosophy and the aforementioned declarations found in Ficino's Three Books on Life, elsewhere in the collection Marullo clearly distinguishes his hymns from petitionary prayers and superstitious invocations intended to change the laws of a necessarily ordained cosmos: "Why, therefore, do we din our inert refrains into the ears of the gods night and day, in vain, and harass Jupiter, who laughs at our prayers and our useless laments $» .^{58}$

On the other hand, Marullo's hymns should not be interpreted - as some critics have done in the past - as some sort of pagan re-enactment foreshadowing the numerous experiments of this kind that characterize modern European

56 VALERY REES, «A Sojourner in Florence: Neoplatonic Themes in the Hymni naturales of Marullus », Acta Conventus Neo-Latini, 16 (2018), p. 559-570.

57 НADOT, Philosophy as a Way of Life, p. 238-250.

58 Marullus, Poems 2.2, p. 226-227, 1. 17-20: «Nam cur interti numina nenia | et nocte frustra obtundimus et die | Iovemque ridentem precesque | totque supervacuas querelas?» The translation is Fantazzi's. 
history ${ }^{59}$ Theurgic prayers, in fact, had played a central role not only among leading Neoplatonists like Proclus, but also in Christian works such as, for instance, pseudo-Dionysius the Aeropagite's On Divine Names. Like Proclus' hymns, Marullo's philosophical prayers are meant to trigger the subject's epistrophe toward the One. As in the pseudo-Dionysius, moreover, the One is conceived as unreachable and theologians, just like poets, are left striving to capture its essence by means of metaphors and conjectures. ${ }^{60}$ Transported by his verses, the poetic persona inscribed in the Natural Hymns experiences an upward process of conversion, which runs opposite to the downward emanation of God's light through the four hypostases. It is because of this transformation that, in the final hymn, the poet can look at the world of mortals as if looking at it from above:

As a last labor the goddess Earth also must rightly be the subject of my song - last, but worthy by her merits of being awarded the first honors. Tower-bearing, fecund, powerful, whom the ancients consecrated with the name of Great Mother, as the inner sanctum of her temple reveals, whether because from her comes the diligent race of men, from her wild beasts and the verdant grassess of the fields, and the woods that cover the heights of Mt. Taygetus, and the pine groves of spiny Mt. Lycaeus, where every race of living creatures lives and increases, each according to its kind $[. . .]^{61}$

Announced in the first hymn and distributed throughout the entire collection, the spiritual transformation narrated in Marullo's collection is best exemplified by the hymn to Bacchus found at the end of the first book. Scholars have often been puzzled by this prayer and tried to resolve it by proposing numerous, and often contrasting, allegorical interpretations. According to Benedetto Soldati, for example, Marullo's Bacchus would be an allegory of divine justice, while for Francesco Tateo the god of wine would refer to eternal youth as a terrestrial

59 According to an authoritative group of scholars, Renaissance paganism would be a nineteenth century cliché, rather than an actual historical phenomenon. On this problem see PAUL 0. KRISTELLER, Renaissance Thought and its Sources, Columbia University Press, New York 1979, p. 6681; John Monfasani, "Platonic Paganism in the Fifteenth Century », in CESARE di Maio (ed.), Reconsidering the Renaissance, Center for Medieval and Early Renaissance Studies, New York 1992, p. 45-61.

60 Pseudo-Dionysius' view of theology had obvious applications to poetry, which were well known since the Middle Ages. A noteworthy example is Dante's Paradiso, as discussed for instance in VitToRio MonTEMAGGI, «In Unknowability as Love: the Theology of Dante's Commedia », in ID. et al. (eds.), Dante's Commedia: Theology as Poetry, University of Notre Dame Press, Notre Dame 2010, p. 60-94.

61 Marullus, Poems 4.5, p. 308-309, 1. 1-8: «Extrema est dea Terra mihi quoque iure canenda, | Ultima, sed meritis quae primos aequet honores: | Turriferens, foecunda, potens, quam nomine Magnae | Sacrarunt veteres adyto monstrante Parentis, | Sive quod inde hominum gnavum genus, inde ferarum, | Quaeque virent campis herbae, quaeque ardua sylvae | Taygeta horrentisque tenent pineta Lycaei, | Unde animale genus generatim vivit adauctum [...]» 
counterpart of Eternity. For Cesare Goffis, who first emphasized Marullo's knowledge of Lucretius, Bacchus would be a personification of nature and its irresistible forces, while for Jacques Chomarat and Walter Ludwig - both of whom were inclined toward a Christian interpretation of the collection - the ancient god would stand for the manifestation of God in history or the Holy Spirit's transformative impact upon the soul of humans.$^{62}$ These different interpretations nonetheless share a common methodology (or assumption), namely that Marullo's collection is a work of literature, albeit one charged with classical allusions and hidden allegorical meanings. If approached as an instance of language of experiential knowledge, by which the author prepares his soul to receive an absolute, non-discursive knowledge, Marullo's hymn to Bacchus is a document of the experimentation and pluralism that characterize Early Modern European religions and spirituality. The imagery, rhythms, and references found in Marullo's hymn can be interpreted as meditative practices, the purpose of which is to rouse the poet's mind from its bodily prison towards heavenly contemplation.

For Neoplatonists and Ficino, Bacchus / Dionysus had already been transformed into a cosmological or spiritual allegory linked to a process of spiritual transformation. In his hymns to Helios and Athena, for example, Proclus had recounted the myth of Dionysus' dismemberment and eventual rebirth as an allegory of the division of the cosmos and the distribution of its elements. In doing so, he interpreted this process as the cosmic counterpart of the philosopher's conversion. ${ }^{63}$ Plotinus, moreover, interpreted this myth as a parable of the soul's fall from the unity of the intellect into the multiplicity of material reality. For Plotinus, Dionysian frenzy is the soul's desire to escape the bodily prison and return to its metaphysical abode. ${ }^{64}$ Ficino, moreover, systematized these Neoplatonic motifs in his famous argumenta attached to Plato's Phaedrus and Ion, in which he described the soul's conversion away from the multiplicity of bodily senses toward the reunion with the One as an ascent

62 BENEDETTO SOLDATI, La poesia astrologica nel Quattrocento: ricerche e studi, Le Lettere, Florence 1986, p. 275; CESARE GOFFIS, "Il sincretismo lucreziano-platonico negli Hymni naturales del Marullo », Belfagor, 24 (1960), p. 386-417; FRANCESCO TATEO, Tradizione e realtà nell'umanesimo italiano, Dedalo Libri, Bari 1969, p. 129-219; WALTHER LUDWIG, « Antike Götter und christlicher Glaube. Die Hymni naturales von Marullo", in Berichte aus den Sitzungen der Joachim Jungius Gesellshaft der Wissenschaften E. V., Hamburg, Verlag Vandenhoeck \& Ruprecht, Hamburg 1992, p. 68.

63 VAn den Berg, Proclus' Hymns, p. 170-74, 280-281.

64 Plotinus, Enneads 1.6.5, trans. STePhen MackennA, Penguin, London 1991, p. 39: « What do you feel in presence of the grace you discern in actions, in manners, in sound morality, in all the works and fruits of virtue, in the beauty of souls? When you see that you yourselves are beautiful within, what do you feel? What is this Dionysiac exultation that thrills through your being, this straining upwards of all your Soul, this longing to break away from the body and live sunken within the veritable self?». 
upon a four-tiered hierarchy consisting of Poetic (Muses), Mysteric (Bacchus), Prophetic (Apollo), and Erotic (Venus) frenzies..$^{65}$ Building creatively on these precedents, Marullo's hymn to Bacchus is fittingly situated at the end of the first book, which symbolically marks the boundary between Ficino's first and second frenzy, as well as the boundary between the spheres of Intellect and World Soul. Framed in the context of Marullo's collection as a whole, in other words, Bacchus constitutes the first step in the poet's spiritual transformation.

Carried away by the frantic rhythm and lists of appellations that characterize Marullo's prayer, readers are invited to create a parallel between the poet and humankind in general. The poet's persona, whose condition of political exile is often used as a cipher of human existence as an exile from the eternal One, manifests his desire to run into pathless woods and join the Bacchantes in their never-ending dances, even howling 'Euoe!' together with the deity's raptured disciples:

Come now, Muses, sing to me of father Bromius, fiery offspring of Jupiter, whom the good Semele brought forth, the boy distinguished by his locks and his radiant eyes. Euoe! My breast sends forth a sound emanating from a frenzied rage and my soul, overflowing with the god, is shaken. Euoe! give me the cymbals, give me the plaintive horns, and may a headband of vipers gird my youthful locks, my locks adorned with ivy, fluttering in the breeze, and in my train may a thousand Edonian women follow after, their sacred feet trembling, with shrill ululations and dancing the wild tripudium, violently shaking their ferine heads under powerful thyrsus, while the rider on his stooped mount repeats the cry 'euoe'!

Possessed by the god, dragged into restless dances and orgiastic ceremonies, forced into a hallucinatory prayer of thanksgiving voiced under Bacchus' influence, the poet presents himself as a symbol of humankind's earthly imprisonment and constant desire to return to the heavenly residence.

But I myself, wandering aimlessly, gasping for breath, led on by overpowering feelings, totally filled with a new spirit, press forward into the pathless woodlands, celebrating the orgies of Bacchus with piercing shrieks, the secret orgia hidden

65 Wouter J. HanegraAfF, «The Platonic Frenzies in Marsilio Ficino », in Jitse H. F. Dijkstra et al. (eds.), Myths, Martyrs, and Modernity: Studies in the History of Religions in Honour of Jan N. Bremmer, Brill, Leiden 2010 (Numen Book Series: Studies in the History of Religions, 127), p. 553-567.

66 Marullus, Poems 1.6.1-12, p. 212-215: "Agedum, canite patrem, Thespiades, mihi Bromium, I sobolem igneam Iovis, quem peperit bona Semele I puerum coma praesignem et radiantibus oculis. | Euoe! sonant furenti mihi pectora rabie | nimioque deo plenus concutitur gravis animus. | Euoe! date cymbalum huc, huc date cornua querula,| cingat virentem mihi taenia viperea comam, | comam diffusam animis Aeoliis hederigeram | quam hinc mille secutae atque illinc trepidante pede sacro, | ululent citatis Edonides usque tripudiis | valido sub thyrso iacientes vi capita fera, | Euoe! sessore pandi geminante quadrupedis ». 
away in a venerated basket, which you would try to touch in vain without a sacred initiation, or without having received nine times the sacred waters of transparent Castalia. ${ }^{67}$

Rather than a declaration of poetics confined to the domain of literature, the poet's description of himself as wandering through the forest guided by Bacchus' frenzy and reviving ancient rituals with the help of poetry is best understood as a dramatic representation of human existence and its authentic spiritual vocation, which the recitation of hymns contributes to awaken. Besides being a tribute to Orphic hymns and their characteristic lists of appellations and epithets such as 'two horned king,' 'satyr,' 'nocturnal,' and 'multiform', Marullo's hymn narrates a gradual movement away from the countless features attributed to Bacchus, toward the discovery of this god's authentic meaning as the organizing principle of the universe - a discovery that, as an illumination, readers can find in the prayer to thanksgiving on which the poem ends:

[...] you balance the weight of the world machine and suspend the earth in the middle of the air in a firm position. Through you we inhabit the remote heights of the heavens, our heavy hearts cheered with too much nectar, you allow us to take our places at the tables of the gods. Hail, benignant source of light, father of gods and men, in your benevolence give aid to those who piously celebrate your mysteries, together with your love one, good Themis. Themis surrounded by the dancing choruses of the Corycian nymphs. ${ }^{68}$

\section{Christianization or Domestication? Gianfrancesco Pico della Mirandola and Natale Conti on Hymns}

Early Modern religious pluralism should not be construed as an idyllic model of peaceful integration of differences. Polemics, disagreement, and polarization, on the contrary, characterize the ways in which European subjects negotiated their religious identities by choosing or rejecting options (e.g. Neoplatonism, Hermeticism etc.) available within their respective religious traditions (Judaism, Islam etc.), while at the same time declaring their affiliation with different institutions of learning (e.g. Universities, monastic or humanistic studia, princely

67 Ibid. 1.6.13-18, p. 214-215: «At ipse vagus, anhelans, animo duce nimio, | Totus noua plenus mente, per auia nemora | Orgia praecedam acutis celebrans ululatibus, | Orgia verendis arcana recondita calathis, | Penitus quae sanctis frustra captes sine initiis, | Nouies perpessus sacra Castalidos vada vitreae ».

68 Ibid. 1.6.53-61, p. 217: «tu libras pondera machinae | medioque terram suspendis in aere stabilem, | per te remota coeli procul ardua colimus, | nimio diffusi praecordia nectare gravia, | tu das deorum sanctis accumbere dapibus. | Salve, benigne lychnita, deum et pater hominum, animoque dexter tua mystica rite colentibus | adsis, tuis non sine amoribus et Themide bona, Themide nympharum stipata Coricidum choris ». 
courts, literary academies, etc.) and preferences for different and, often, competing claims to knowledge. ${ }^{69}$ Acceptance or rebuttal of what Robert Bellah, in his influential essay on the religions of Italy, called the 'ground bass' of preChristian religions, for instance, is one among many long-lasting options available in the constitution of a religious identity not only in the Early Modern period, but well into the civic rituals and political religions of late nineteenthand twentieth-century Europe. ${ }^{70}$ If one contrasts, for instance, the dramatically different perceptions of ancient prayers and rituals adopted, for instance, by Roman Cardinal and Augustinian Hermit Giles of Viterbo (1472-1532) with the stark exclusivism of Girolamo Savonarola (1452-1498), it is evident how individual approaches to what is polemically, and somewhat misleadingly, designated as paganism, are defining identity markers. ${ }^{71}$ Polemics, polarization, and different attitudes in regards to the alterity of non-Christian prayers, as the cases of Gianfrancesco Pico della Mirandola (1469-1533) and Natale Conti (15201582) illustrate, characterize the reception of Neoplatonic hymns in the aftermath of Ficino.

If Marullo's Natural Hymns enthusiastically followed Ficino's adoption of ancient hymns as instruments of meditation and divine intercession, at the same time this practice could be controversial. Ten years after the publication of Marullo's poetic work, Gianfrancesco Pico della Mirandola, himself a prolific composer of hymns in elegant Latin hexameters, voiced a widespread criticism of the overwhelming presence of ancient mythology in early sixteenth-century literature ${ }^{72}$ In order to contrast such a trend, in 1507 the humanist published a collection of three hymns known as Hymni heroici tres. Pico's hymns, dedicated respectively to the Trinity, Jesus Christ, and the Virgin Mary, were supposed to act as a counter-chant to what the author perceived as an overwhelming wave of paganizing poetry. In the short dedication to the author's young son Thomas, Gianfrancesco stated that indignation was at the origin of the project. He was inspired to undertake it after having witnessed too many contemporaries

69 Von STUCKRAD, Locations of Knowledge, p. 19-20; Giovanni Filoramo, «Religious Pluralism and Crises of Identity », Diogenes, 50/3 (2003), p. 31-44.

70 Robert N. Bellah, Philip E. Hammond, Varieties of Civil Religion, Harper and Row, San Francisco 1980, p. 90-94.

71 Matteo SoRAnzo, Poetry and Identity in Quattrocento Naples, Ashgate, Farnham 2014, p. 117-141; ID., " Exploring the Forests of Antiquity: the Golden Bough and Early Modern Spirituality ", in BILL GladHill, MicaH Myers (eds.), Walking Through Elysium: Aeneid 6 and Its Cultural Reception, Toronto University Press, Toronto 2019, p. 77-93.

72 CLAUDIO MORESCHINI, Rinascimento cristiano. Innovazioni e riforma religiosa nell'Italia del Quindicesimo e Sedicesimo secolo, Edizioni di Storia e Letteratura, Roma 2017, p. 163-218; MATTEO SoRANzo, "Un'identità religiosa nel primo Cinquecento: gli Hymni Heroici Tres di Gianfrancesco Pico della Mirandola ", Italian Studies, 70/1 (2015), p. 53-75. See also MArco PIANA, "Fallax Antiquitas: Gianfrancesco Pico Della Mirandola's Critique of Antiquity », Ph.D. Diss., McGill University 2018. 
addressing hymns to Pan, Hera, Venus, and other false deities with a zeal that surpassed, in his view, that of the ancient pagans themselves. Like Ficino, Marullo, and their Neoplatonic predecessors, Gianfrancesco did acknowledge the necessity of singing hymns to relax the mind and prepare it for receiving divine mysteries. In Gianfrancesco's view, however, pagan gods were nothing but demons in disguise, who could take possession of the softened minds of whoever would address them with prayers:

I saw that numerous poets of our time are corrupting all things: they address their prayers to Pan, Earth and Venus under the image of nature. They invoke all the gods and goddesses, draw down the spirits of stars, conjure up ghosts and summon the dead, performing pagan rituals with more zeal than the pagans themselves. So, I decided that it was no more acceptable for young students to swallow, under the pretext of elegance and erudition, the venom of a false religion covered, as it were, in honey. And above all, I wanted to warn you against this danger. ${ }^{73}$

Consistent with these premises, Gianfrancesco Pico's self-annotated Hymni heroici tres foreshadowed three tendencies in the reception of this important aspect of Ficino's influence on Early Modern prayer. First of all, in each of the proems of his collection of hymns and the long annotations added to the first edition, Gianfrancesco, consistent with Thomas Aquinas and his condemnation of invocations addressed to pagan gods, harshly rejects the pseudo-Dionysian idea that divine names are attributes of the only true God. According to the author, hymns should be addressed only to conventionally Christian interlocutors such as the Trinity, Christ, the Virgin Mary, and the sanctioned angels and saints. ${ }^{74}$

This position, which Gianfrancesco embraced in his own production of hymns, is exemplified in the opening poem of his collection, a long hymn to the Holy Trinity. The poem opens with a long rebuttal of pagan imagery and models, which Gianfrancesco labels as Satan's tools made to distract humans from the divine truth. ${ }^{75}$ Modeling his poetic persona on Moses, the author adopts the

73 Gianfrancesco Pico della Mirandola, Hymni Heroici Tres, Minutianum, Milan 1507, fol. 1r: « Itaque conspicatus a plerisque nostre tempestatis fedari omnia sub naturae velamine Pana, Tellurem, Venerem invocari et deos deasque omnes accersiri, et animas a stellis derivari et umbras elici et manes evocari et deos gentium in presentia magis quam a gentibus ipsis celebrari dissimulandum amplius non putavi ne sacris litteris parum eruditi adulescentes sub comptae et eruditae linguae praetextum quasi melle illita falsae religionis venena deglutiant et in primis te periculi huius non mediocris admonitum volui ».

74 Ibid., fol. 1.

75 Ibid., fol. $3 \mathrm{v}-4 \mathrm{v}$ : « Summe parens rerum qui vastas flectis habenas | orbis et eterno dispensas omnia nutu, | da, precor, optatas edenda in carmina vires. | Non tamen Auratam Pellem de Phasidis ora | poscimus antiqua Minyarum avertere puppi, | non Laertiaden, Pelideae aut gesta ferocis | non Thebas, profugumque ducem phrygiosque nepotes | tollere mendaci suprema ad sydera cantu; | nec iam Threicio libamina dicta poetae | non Cyreneo laudes effundere plectro, | 
structure of the ancient hymn only to replace its idolatrous contents with the stories of the Bible. ${ }^{76}$ The hymn to the Trinity retells the history of creation to emphasize the rupture between humans and Nature that followed the Fall, presenting the transformation of natural phenomena into gods as the result of a demonic conspiracy against God and humankind. Consequently, the composition of Christian hymns is aligned with the history of Redemption, as the poet presents himself as actively collaborating with Christ's redemptive mission. ${ }^{77}$

Pico's poems had little success in Italy, grounded as they were in the author's personal acquaintance with Girolamo Savonarola and the Florentine current of intransigent Christians known as Piagnoni. Gianfrancesco's take on hymns, however, had long-lasting success on the other side of the Alps. ${ }^{78}$ Along with Erasmus of Rotterdam and Joseph Scaliger - who both despised contemporary revivals of hymns addressed to pagan gods and harshly criticized this aspect of Marullo's poetry - even John Milton might have been acquainted with Pico's poetical works, as Blossom Feinstein has persuasively argued..$^{79}$ Despite the

nec Salaminiaci numerosa precamina vatis; | non quae Trinacriae cantavit rustica Musa, | non quae ad Olympiacae quinquennia praemia palmae | concinuit Dircaea chelys defensa per ignes ». [Highest father of things, who hold the vast reins of the world and provide all things with your eternal will, give me, I pray you, the strength I desire for composing my poem. But I am not asking you to transport once again the Golden Fleece from the banks of the Phasis river on the Mynians' boat, nor to extol to the skies Odysseus, Achilles' fierce deeds, Thebes, the wandering king and the Phrygian descendents with mendacious verses; nor what the Sicilian Muse sang, the countless prayers of the poet of Salamis and those that the Dircean lyre sang every five years in honor of the Olympic winner].

76 Ibid., fol. 6v-7r: « Dic mihi sacratis radiatus tempora Moses | cornibus, unde uni famulatur et infimus orbis | et summus? Tibi namque patet quem fumida nubes | conclusit, postquam turba comitante fideli | difrjciens virga fluctus Rubri Aequoris altos | duxisti solido vestigia sicca profundo. | Inde per arentes arabum tentoria ampos | liquisti aerio considens vertice Synae | colloquioque fruens metuendi principis, illo | contentus gustu ieiunia longa tulisti | et Christo assidens praecelsi montis amoeno | vertice de liquida potas mysteria nube ». [Tell me, Moses, glowing with your sacred horns: why do the lowest and highest spheres obey one principle? You know it well: a cloud of smoke was shrouding you, when you, parted the water of the Red Sea with your staff and marched with your followers on the bottom of the sea without getting your feet wet. Then you left the camps scattered in the Arabian desert and sat on the windy top of Sinai: conversing with the awesome Prince, you fasted for a long time, feeding only on that flavor. Sitting with Christ on the sunny top of the mountain, you drink in mysteries from that limpid cloud].

77 MoResCHINI, Rinascimento Cristiano, p. 163-218; SoRAnzo, « Un'identità religiosa », p. 68-70; PianA, «Fallax Antiquitas », p. 142-148.

78 On this subject, see Steven Rowan, GerhiLd Scholz Williams, « Jacob Spiegel on Gianfrancesco Pico and Reuchlin: Poetry, Scholarship and Politics in Germany in 1512 ", Bibliothèque d'humanisme et Renaissance, 44/2 (1982), p. 291-305. See also PIANA, « Fallax Antiquitas », p. 73-77.

79 Blossom Feinstein, "On the Hymns of John Milton and Gian Francesco Pico ", Comparative Literature, 20/3 (1968), p. 245-253. Erasmus' critique of Marullo is found in his 1524 letter to Haio Herman; see The Correspondence of Erasmus (Letters 1356-1534), trans. ROGER AUBREY BASKERVILLE Mynors, AleXander Dalzell, Toronto University Press, Toronto 1992, p. 344. As for Scaliger, his 
modest success of Pico's hymns in Italian lands, his lesson was received by a few select poets, among which we find Giano Vitale (1485/90-1559 ca.). Following in Pico's footsteps, the Sicilian poet composed several religiously sound hymns in elegant humanistic Latin. In 1516, for example, Vitale printed a first collection of three hymns entitled In Divos Archangelos Hymni. The collection consisted of three prayers to the archangels Michael, Gabriel, and Raphael, dedicated respectively to Antonio Nerli, Girolamo Vida and Alberto III, prince of Carpi, who were prominent followers of Pope Leo X and members of the Medici's entourage in Rome. This work was soon followed by Vitale's In Divinam Trinitatem Hymni Tres printed in 1517, which is a collection of new hymns dedicated to other illustrious followers of Leo X such as Pietro Bembo (1470-1547), and Jacopo Sadoleto (14771547). Presented as the work of a Christian vates enlightening Orpheus' hymns with Christian truth, Vitale's hymns are meant to constitute the liturgical counterpart of the classicizing reform of Roman Catholic liturgy pursued by the Medici popes Leo X and Clement VII. ${ }^{80}$

Intransigent Christians recurrently complained about the widespread use of pagan imagery in the literature of the time. Nevertheless, meditative and performative hymns addressed to pagan deities and personifications of philosophical and astrological concepts managed to survive even the attempted purification of the Christian message brought about by the Reformation. Besides allegory, which continued to offer a viable way for attenuating the otherness of pagan gods, a widespread tactics was a newly found interest for the form, rather than the content, of ancient prayers. Gianfrancesco Pico himself had to acknowledge that ancient hymns were still valid formal models for a reform of Christian hymns, even if they are addressed to false gods. Others argued that pagan prayers and rituals could be studied, analyzed, and formally imitated at least for scholarly purposes, so long as their addressees did not become actual objects of worship. This view was embraced by Pico's friend Lilio Giraldi, who not only composed lengthy erudite treatises on the religions of antiquity, but also actively collaborated in the publication and diffusion of Gianfrancesco Pico's works, thus showing his support for his friend's approach to ancient hymnography. ${ }^{81}$ The same fascination with ancient rituals and prayers, moreover, can be seen at work in the eccentric, yet extremely influential, Mythologiae (first printed 1567) composed by Natale Conti (1520-1582).

negative judgment is found in book 6 of his Poetices libri septem, Jean Crespin, Geneva 1561, p. 299.

80 On Giano Vitale, see PaOla DE CAPUA, «Tra Giano Vitale, Pietro Corsi e Niccolo Ridolfi », Studi medievali e umanistici, 15 (2017), p. 451-512.

81 SIMONA Fò̀, «Giraldi, Gregorio Lilio », in Dizionario biografico degli Italiani, Treccani, Rome 2001, vol. 56, 452-455. See also PIANA, « Fallax Antiquitas », p. 166-167, 219-223. 
If Ficino and Marullo found a renewed way to negotiate their religious identity and enrich their spirituality in ancient wisdom and practice, Conti's post-Tridentine approach to ancient religions and rituals oscillated between skepticism and acceptance, often softened by the use of allegory. On the one hand, Conti acknowledged that certain aspects of paganism, if properly interpreted, have the power "to raise men to the heights of celestial knowledge ${ }^{82}$ On the other hand, as John Murlyan and Steven Brown have stated, Conti's attitude shifts between contempt and derision toward the presumed immorality of pagan myths and « respect for the occult wisdom contained in its narratives $\gg .^{83}$ This ambivalent position is exemplified in the section on hymns of Conti's Mythologiae (I, 16). Written to show the simplicity of ancient people and their gods, the chapter engages with the difficult task of explaining ritual hymn-singing. ${ }^{84}$ Based on his knowledge of the hymns of Callimachus and Orpheus, Conti describes these prayers as part of a ritual divided into two consecutive phases. First, hymns inscribe an invocation to the deity, in which the god's epithets and powers are enumerated together with the blessings he/she bestowed upon the population. Second, hymns incorporate an actual petition, which culminates in beseeching the divinity's favor. ${ }^{85}$ In doing so, Conti projected the most controversial elements of hymn-singing upon the distant, primitive, and ultimately harmless, horizon of antiquity.

Ficino substantially emphasized the power of hymn-singing as an instrument for realigning the soul with God, a practice coherent with the purposes of a Christian life. Conti's book, on the other hand, describes hymns as one among the multiple aspects of a pagan ceremony, thus presenting the meditative properties and spiritual efficacy of these prayers as the curious output of a foreign spirituality. In these ceremonies, he states, the ancients used music « to shift the minds of those who were present there from their own thoughts to the worship of the immortal gods ${ }^{86}$ By setting hymn-singing in the far-away world of antiquity, or by soothing their disruptive potentials with the aid of allegory,

82 Natale Conti, Natale Conti's Mythologiae, trans. John Mulryan, SteVen Brown, ACMrS, Tempe 2006 (Medieval and Renaissance Texts and Studies, 316), p. 3.

83 ConTI, Mythologiae, p. xxxv.

84 Ibid., 47: "Our readers might gain some profit and pleasure from a brief explanation of the different kinds of hymns employed by the ancients in their sacrifices. It would go a long way toward explaining not only the simplicity of those people, but also the nature of the gods they worshiped».

85 Ibid., 49: «To put it as briefly as possible, the structure of a hymn commonly consists of the following elements: a foreshadowing of the arrival of the gods through a generous display of happiness everywhere; songs sung at the altar that glorify the gods and their achievements; recollections of the favors that the gods have bestowed upon men; and finally, prayers requesting the kind and blessed attendance of the gods at the sacrifices being conducted in his honor ».

86 Ibid., 32. 
therefore, Conti managed to create a critical distance between his world and that of this ancient devotional practice, thus adjusting Ficino's legacy to the stricter criteria of religious orthodoxy of late-sixteenth-century Europe. Rather than an ancient meditative practice to pursue and revive, in Conti's Mythologiae hymns are presented as the equivalent of a pagan festival or ancient practices such as display of ceremonial garlands and the performance of sacrifices. ${ }^{87}$

As a result of Gianfrancesco Pico's early rebuttal of pagan mythology and Natale Conti's antiquarian rationalization of pre-Christian prayers, in sixteenthcentury Italy the revival of meditative hymns began to develop into essentially two forms. On the one hand, Neoplatonic hymns to intermediary deities such as those found in Marullo's Hymni Naturales were allegedly absorbed into a Christian paradigm by substituting pagan deities with theologically acceptable addressees, such as God, Jesus Christ, the Virgin Mary, angels, and saints. On the other hand, despite the survival of Neoplatonic approaches to prayer, hymns became progressively relegated to the past, and were revived mostly for antiquarian interests. In both cases, however, hymns drifted away or were progressively excluded from philosophy's domain together with rituals, natural magic and the spiritual practices philosophy entailed for ancient and Renaissance authors. On the subject of Christianizing hymns, once again, Gianfrancesco Pico was at the forefront of this largely unexplored trend.

In 1531, a few years before Gianfrancesco's death, his friend Lilio Giraldi published a new edition of the three hymns composed in 1507 supplemented with ten new hymns accompanied by a dedicatory letter addressed to Neapolitan poet Jacopo Sannazaro. In this collection, Giraldi included Pico's meditative prayer addressed to his Guardian Angel, a text which adapts the structure of an Orphic hymn to a popular theme in Christian devotion with a vivid autobiographical spin. Written in the midst of the fratricidal wars that lacerated the author's family's inheritance, Pico's hymn interprets the Guardian Angel's power over the dangerous actions of demons as both a spiritual replication of Christ's Harrowing of Hell in the company of Michael, and as the soul's conversion away from the prison of the senses toward the contemplation of God:

Although the Ancient Serpent, as if repeating the ancient sin, often instills temptations and bad decisions in my heart, you still descend in the hardened soul with your constant whisper and rekindle the light of my intellect: straighten my eyes that are wandering, turn them toward the heavens as they are falling down. This way, they may get used to contemplate the eternal homeland of heaven and

87 Ibid., 22: « During the sacrificial proceedings themselves, the victims, the altars and the men who performed the sacrifice wore garlands ». See also Ibid., 23: «Since different trees were sacred to different gods, priests decorated themselves in different types of wreaths before sacrificing to a particular god ». 
write God's commands upon the heart. What is a sin, and I confess my sin, already shames me: ask the highest Father to forgive me and reunite me to him with sacred love, and may he set my heart on fire with heavenly flames. ${ }^{88}$

Scattered with allusions to tragic events such as the siege of Mirandola and the ephemeral truce that preceded Gianfrancesco's assassination, the hymn also offers a snapshot into the tormented spirituality and demonic obsessions of this still largely unknown poet and philosopher.

\section{Hymns and Spirituality at Court}

So far, this essay has illustrated how the inclusion of Neoplatonic hymns among the spiritual practices adopted by Renaissance philosophers constitutes a challenge to what is conventionally meant by 'philosophy'. Ficino, Marullo, Conti, and Pico, however, would also be problematic characters in a history of Early Modern spirituality, as none of them is, for instance, affiliated with a monastic order or committed to an ascetic life solely directed to the contemplation of God. Problematic as they might be for conventional definitions of philosophy and religion, these authors are perfectly understandable in terms of what Michel Foucault, in his Hermeneutics of the Subject, defined as spirituality. Rather than being linked to a specific religious tradition, Foucault argued, spirituality is best understood as the "search, practice and experience through which the subject carries out the necessary transformations of himself in order to have access to the truth $»{ }^{89}$ Together with the " purifications, ascetic exercises, renunciations, conversions of looking, modifications of existence » listed by Foucault, we suggest that meditative prayers and the language of experiential knowledge might be interpreted as instances of a pre-Cartesian discourse, which constructed knowledge as attainable only by the transformation of the knowing subject. The last section of this essay will further explore this point by looking at the survival of Neoplatonic hymns in the arts and literature produced on the other side of the Alps.

In the company of painters, sculptors, and poets, so to speak, this peculiar spirituality made its way from Ficino's Florence to many prestigious European

88 GianfRAnCEsco Pico, Hymni Heroici Decem, sig. C iii v: « Quamquam saepe novas artes, nova pectore versat | consilia antiquus geminato vulnere serpens, | ipse autem crebro in praecordia dura susurro | illapsus nostrae defigens lumina menti | compesce errantes oculos, et in ima ruentes | erige, ut in coelum patriam spectare perennem | assuescant, cordi infigens mandata tonantis | et quod peccatum est (peccatum quippe fatemur) | iam nos poeniteat, summum exorato parentem | det veniam, secumque sacro nos iungat amore | semper, et aethereis succendat pectora flammis ».

89 Michel Foucault, The Hermeneutics of the Subject, Lectures at the Collège de France (1981-1982), ed. FrÉDÉRIC Gros et al., Palgrave, New York 2005, p. 15, 19. 
courts, such as those of Henri II's France and Queen Elizabeth's England. The Platonic conception of the work of art as an instrument of meditation, which serves to arouse the minds of readers by guiding them toward the contemplation of heavenly forms, became a distinctive form of experiential knowledge cultivated in northern European courts. This observation is consistent with what Sir Ernst Gombrich, a trailblazer in this area of studies, argued about the ancient gods populating Renaissance palaces, galleries and ceilings. These iconographic motifs, Gombrich contended, should not be taken simply as the visual substitutes of abstract concepts whose purpose was to teach concepts without using words. Rather, symbolic images - as Gombrich called them - were considered parts of an interconnected cosmos, in which God manifests abstract ideas through symbols scattered in nature, the function of which is to raise human minds from their bodily prisons toward the contemplation of invisible truths. ${ }^{90}$ This concept must be applied not only to the courts and villas of the Italian Renaissance, but to the entire Early Modern period in Europe. While preserving their original function as spiritual exercises acting upon the minds of the reader, in this context, hymns addressed to pagan gods and philosophical concepts could survive within the safer sphere of art and literature. Pierre de Ronsard (1524-1585) and Edmund Spenser (1552-1599) will further illustrate this last, and final, point.

Scholars have often argued that Renaissance Neoplatonism had a direct impact upon Pierre de Ronsard's poetry, and most importantly upon the numerous hymns he composed between 1555 and $1563 .{ }^{91}$ Jean Ceard, for example, has persuasively demonstrated how the overall structure of Ronsard's collection of hymns was meant to mirror the Neoplatonic dichotomy between intellectual and earthly spheres. Ceard, moreover, has emphasized the role Jean Daurat (1508-1588) played in translating ancient philosophical themes for Ronsard and other poets of the time..$^{2}$ Building on this tradition of studies and on Gombrich's

90 ERnst Gombrich, «Icones Symbolicae: The Visual Image in Neo-Platonic Thought », Journal of the Warburg and Courtauld Institutes, 11 (1948), p. 146, 170.

91 On this subject, see the still relevant cluster of essays published in 1960s and 1970s, originating from the pivotal Alfred W. SATterthwaite, Spenser, Ronsard, and Dubellay, Princeton University Pres, Princeton, NJ, 2016. Originally published in 1960. HENRY HORNIK, « More on Ronsard's Philosophy: The Hymns and Neoplatonism ", Bibliothèque d'Humanisme et Renaissance, 27/2 (1965), p. 435-443. See also Apostolos P. KouidIs, « Ronsard's Four Hymns to the Seasons: A Glorification of the Benevolent World", Kentucky Romance Quarterly, 22/2 (1975), p. 223-234. TERENCE C. CAVE, « Ronsard's Bacchic Poetry: From the Bacchanales to the Hymne De L'autonne », L'esprit créateur, 10/2 (1970), p. 104-116. Donald StonE, « The Sense and Significance of Ronsard's Seasonal Hymns », Symposium: A Quarterly Journal in Modern Literatures, 18/4 (1964), p. 321-331. ISIDORE SILVER, « Ronsard's Reflections on Cosmogony and Nature », PMLA, 79/3 (1964), p. 219233.

92 JEAN CEARD, «Dieu, les hommes et le poète: structure, sens et fonction des mythes dans les Hymnes de Ronsard», in MAdeleine LAzARD (ed.), Autour des Hymnes de Ronsard, Champion, Paris 1984 (Unichamp, 7), p. 83-101. 
interpretation of Renaissance Neoplatonic symbolism, Philip Ford concluded his monograph on Ronsard's hymns by explaining the countless and often remote mythological references scattered in these texts in light of the philosophy of Plato, Proclus and Ficino. Adapting Gombrich's insight to the analysis of Ronsard's hymns, Ford has persuasively argued that these texts use mythological allegories of philosophical concepts as symbolic images. Their purpose, therefore, is not simply packaging erudite notions in an embellished form but rather preparing the reader's mind to the contemplation of otherwise unspeakable truths. $^{93}$

Ronsard elaborated his conception of hymns as instruments of spiritual transformation through a close intertextual dialogue with Marullo's Natural Hymns and, specifically, with Marullo's hymn to Bacchus. According to Ford, Ronsard's hymn to the god of wine and mysteric frenzy marks a turning point in the poet's rediscovery and mastering of the ancient liturgical form; a turning point, moreover, that owes much to Florentine Platonism at large. Besides the similarities with Callimachus, Homer, and Orpheus, Ronsard's hymn to Bacchus reveals a number of elements that strongly recall Marullo's work..$^{94}$ Although, at first sight Ronsard's account of mysteric frenzy recalls a drunken state of euphoria rather than the Mysteric frenzy evoked in Marullo's collection, the god that rises from the midst of the orgy pertains to the same semiological paradigm. As Marullo, Ronsard ascribes to Bacchus the guardianship over the balance of the Cosmos and the guidance of the dance of the elements in the sublunary world, thus creating a direct link between his work and Marullo's meditative and petitionary prayers to the gods. ${ }^{95}$

Ronsard's hymn betrays the view of hymns as spiritual exercises and the theurgical function of ancient prayers revived in Ficino's Florence. The epistrophe staged in Ronsard's hymns culminates in the Hymn to Autumn, in which the poet recounts the story of his poetic inspiration as a lifelong dialogue with the ancient gods:

On the day that I was born, Apollo, who presides over the Muses, acted as my guide in this world, animated me with a penetrating and active mind, and made me love knowledge and honour. Instead of the great treasures and the worthless riches that dazzle the eyes of human beings, he gave me as my birthright the fury of inspiration, and the art of skillfully putting my lively imaginings into writing. He exalted my heart and exalted my imagination, inspiring my soul with a gift for

93 PHILIP FoRD, Ronsard's Hymnes: A Literary and Iconographical Study, Medieval \& Renaissance Texts \& Studies, Binghamton 1997, p. VII-VIII, 9.

94 Ibid., 120.

95 Ibid., 125. 
Poetry, which god has granted only to those minds spurred by the sharp goads of his Divinity. ${ }^{96}$

The hymn to Bacchus stages a ritual offering by which the officiant's soul is turned away from the prison of the body toward the contemplation of the cosmic harmony embodied by the god. In the Hymn to Autumn, instead, the conversion has already taken place and the poet can look back at his past acknowledging the supernatural origin of his inspiration:

I followed the dance, and fearfully pressed my steps into the prints of the Nymphs, and I thought that by placing my feet in their dusty tracks my soul would immediately become more noble, just like that of Ascrean, who uttered solemn poetry when one of the nine Sisters presented him with Laurel. ${ }^{97}$

The poet regains his ancient role of prophet inspired by the deities, animated by a godly madness that drives his work of art. Poetry, therefore, becomes the key to obtaining the infinite knowledge of the gods by summoning their power in the context of a ceremony taking place within the domain of literature.

Another case of spiritual hymns in Early Modern Europe can be found in Edmund Spenser (1552-1599). Scholars agree that the author had a profound knowledge of Marsilio Ficino and Renaissance Neoplatonism. Valery Rees, for example, has thoroughly investigated Spenser's potential access to library holdings, focusing on the central role played by Ficino's translations and commentaries in the poet's approach to Plato's texts and ideas. ${ }^{98}$ Eugene Hill, moreover, has discovered a series of correspondences between Spenser's take on Platonic ideas and other philosophers from Elizabethan England such as Everard Digby, thus contextualizing the poet's notion of a kind of transformative knowledge that produces changes in the subject in the broader English reception

96 Pierre Ronsard, Selected Poems, trans. Malcolm Quainton, Elizabeth Vinestock, Penguin, London 2002: Hymne de l'Autonne, p. 73, 1. 1-16: « Le jour que je fut ne, Apollon qui preside | Aux Muses, me servit en ce monde de guide, | M'anima d'un esprit subtil et vigoureux, | Et me fist de science et d'honneur amoureux. | En lieu des grands thresors et de richesses veines | Qui aveuglent les yeux des personnes humaines, | Me donna pour partage une fureur d'esprit, | Et l'art de bien coucher ma verve par escrit. Il me haussa le cœur, haussa la fantasie, | M'ispirant dedans l'ame un don de Poësia, | Que Dieu n'a concedé qu'a l'esprit agité | Des poignans aiguillons de sa divinité ».

97 RoNSARD, Selected Poems: Hymne de l'Autonne, p. 73, 1. 43-48: «J'allois apres la danse, et craintif je pressois | mes pas dedans le trac de Nymphes, et pensois | que pour mettre mon pied en leur trace poudreuse |j'aurois incontinent l'ame plus genereuse: | ainse que l'Ascrean qui gravement sonna | quand l'une des neuf Soeurs du Laurier luy donna ».

98 VALERY ReEs, « Ficinian Ideas in the Poetry of Edmund Spenser » in KenNETH BORRIS, Jon QuitsLund, CARol Kaske (eds.), Spenser Studies XXIV, AMS Press, New York 2009, p. 73-134. 
of Plato's texts. ${ }^{99}$ It is mostly thanks to Kenneth Borris, however, that Spenser's reuse of Platonic themes in his poetic works, and most importantly in his Faerie Queene and Fowre Hymnes, has been recently scrutinized and traced back to its original sources. Among the multiple Platonic themes recognizable in Spenser's literary works, Borris has indicated a view of poetry as a tool for enlightening human souls, which invests the divinely inspired poet with a solemn ethical and political function. Spenser's Hymnes, in Borris' perspective, are thus to be interpreted as tools for preparing the reader to grasp an otherwise unreachable truth, which dwells above words and human understanding. ${ }^{100}$

Besides giving evidence of a close dialogue with Plato and his Early Modern interpreters, Spenser's Fowre Hymnes can thus be read as a conscious reappraisal of Ficino's meditative prayers. Organized into two parts each consisting of two hymns, Spenser's collection juxtaposes the earthly manifestations of Love and Beauty with their heavenly counterparts, which the poet platonically situates in the world of Ideas. By means of elaborate invocations placed in four closely interconnected proems, and through carefully phrased prayers situated in the closing lines of each hymn, Spenser's collection not only conducts a thorough discussion of central concepts in Plato's philosophy, but also stages an itinerary of spiritual transformation explored in its aesthetic, ethical, and epistemological aspects. More precisely, the four hymns chart the poet's progressive detachment from earthly things and passions by means of a long meditation on how Love and Beauty manifest themselves in history and the cosmos, which accompanies the reader to the final contemplation of heavenly Beauty. This four-tiered process, which is modeled on Diotima's ladder in Plato's Symposium as well as on Ficino's notion of four frenzies, culminates in the opening lines of the third text of the collection, which marks the boundary between physical and ideal love. Only with Love's help, the poet declares in his Hymne of Heavenly Love, he will be able to transform himself and see things from the point of view of eternity, a transformation that, for Spenser, is both moral and artistic:

Love, lift me up upon thy golden wings, | from this base world unto thy heavens hight | where I may see those admirable things, | which there thou workest by thy souveraine might, |farre aboue feeble reach of earthly sight, | that I thereof an heavenly Hymne may sing | unto the god of Love, high heavens king. | Many lewd layes (ah woe is me the more) | in praise of that mad fit, which fooles call loue, | I have in th'heat of youth made heretofore, | that in light wits did loose affection

99 Eugene D. Hill, «Everard Digby: A Syncretic Philosopher at Spenser's Cambridge », in BoRRIS, QUITSLUND, KASKE (eds.), Spenser Studies XXIV, p. 135-154.

100 Kenneth Borris, «Platonism and Spenser's Poetic », in Borris, Quitslund, KasKe (eds.), Spenser Studies XXIV, p. 209-269, especially 211-212, 214, 218-219. 
move. | But all those follies now I do reprove, | and turned have the tenor of my string, | the heavenly prayses of true loue to sing. ${ }^{101}$

Differently from Gianfrancesco Pico, however, Spenser's use of Scriptural imagery does not stem from polemical purposes or a critical attitude toward other literary expressions of the time. Much like Ronsard, whose hymns he certainly knew and imitated, Spenser interprets the process of spiritual change as a transformation of his skills as a poet and a philosopher. More than a meditative practice used to enrich Christian spirituality with elements extracted from a foreign religion, once again, Spenser's hymns revive ancient prayers in the context of a defense of poetry, prudently confined within the boundaries of literature.

\section{Conclusion}

Although selective and ultimately incomplete, this essay illustrates how the rediscovery of Neoplatonic hymns brought about a new form of spirituality that blurs the boundaries of philosophy and religion..$^{102}$ The progressive exclusion of this spiritual practice from the domain of philosophy, as well as its containment within the reassuring borders of antiquarianism and literature, moreover, gives partial evidence of how the modern-day dichotomy between rational and experiential knowledge might have gradually come about. If philosophers, so to speak, do not pray anymore, it is because of very specific circumstances, which our short history of philosophical hymns has attempted to illustrate. Rather than belonging to essentially incompatible domains, philosophy and prayers have actually often crossed paths in the course of Western cultural history, and notably during late Antiquity and the Renaissance. Sometimes, as in the case of Ficino and Marullo, the peculiar experience aroused by hymn-singing was perceived as complementary to philosophical inquiry. At other times, instead, hymns were condemned for using non-Christian elements, rewritten according to Catholic orthodoxy, projected upon the foreign background of antiquity, or situated within the safer boundaries of literature. Either way, hymn-singing and the form of knowledge this practice entails were at least available to negotiate one's identity in a pluralistic field of options and possibilities. While this spiritual

101 Edmund Spenser, The Fowre Hymnes, ed. Lilian Winstanley, Cambridge University Press, Cambridge 1903, vol. III, p. 1-14.

102 In this sense, the revival of Neoplatonic hymns also instantiates a recurrent phenomenon in European religious history, that is, the development of new religious practices out of the scholarly investigation of past or foreign cultures. An excellent and, to our knowledge, unrivaled analysis of this entanglement between scholarship and spirituality is VoN STUCKRAD, The Scientification of Religion, p. 114-177. 
practice, as we contend, was progressively excluded from the domain of philosophy, one wonders whether it might have nevertheless survived and, if so, which form, disciplinary status and purposes it might have acquired in other historical contexts.

Answering these questions, of course, would go beyond the limits of this essay. The hymn to the Sun Tommaso Campanella (1568-1639) composed from the prison cell where the Holy office held him captive on charges of heresy, however, might offer an instructive example of this kind of survival. Written on an Easter Sunday between 1605 and 1609, while the philosopher was confined to the dungeons of Castel Sant'Elmo in Naples, Campanella's hymn to the Sun epitomizes the power ascribed to, together with the problematic nature of, the form of prayer discussed in this essay. Composed in the midst of CounterReformation Italy, Campanella's prayer is addressed against both the materialistic worldview professed by natural philosophers linked with universities, and the dogmatism of theologians, who both denied the Sun's intrinsically divine essence. Campanella's hymn, therefore, might be interpreted as a late tribute to Ficino's legacy, and to other attempts at grafting onto Christian spirituality ancient spiritual practices made available by humanistic scholarship. In consciously adopting a spiritual practice rejected by orthodox Christians as well as university-based philosophers, moreover, Campanella weaponized, so to speak, hymn-singing to craft his untamed identity in open conflict with the mainstream culture of the time:

People wrote to you denying sense and life, $\mid$ and they made you worth less than flies. | I wrote that they were heretics, rebellious and ungrateful to you; | they buried me, because I vindicated you. | The flies and enemies receive joy from you; | so it must follow that it is better to be a fly or your enemy. | No one will pay attention to you if I remain darkened: | that great title of yours shall remain buried with me. | You are a living temple, statue and venerable countenance, | the magnified and supreme face of the true God. | Father of nature and blessed king of the stars, | life, soul, and sense of every secondary thing; ${ }^{103}$

103 Tommaso Campanella, Le poesie, ed. Francesco Giancotti, Einaudi, Turin 1998, p. 89, 1. 31-42: "Scrissero le genti a te senso e vita negando, | e delle mosche fecerti degno meno. | Scriss'io ch'egli erano eretici, a te ingrati e ribelli; | m'han sotterrato, vindice fatto tuo. | Da te le mosche e gl'inimici prendono gioia | esserti, se seguiti, mosca o nemico meglio è. | Nullo di te conto si fara, se io spento rimagno: | quel tuo gran titolo meco sepolto fia. | Tempio vivo sei, statua e venerabile volto, | del verace Dio pompa e suprema face. | Padre di natura e degli astri rege beato, | vita, anima e senso d'ogni seconda cosa ", English translation in Tommaso CAMPANELLA, Selected Philosophical Poems of Tommaso Campanella: A Bilingual Edition, trans. SHERRY RousH, University of Chicago Press, Chicago 2011, p. 186. 
Alongside its broader historical significance, Campanella's hymn is thus the tragic assertion of an antagonistic religious identity. As he turned his eyes to the Sun like the ancient sages brought back to life by humanistic scholarship, Campanella situated himself among and against the numerous options that define Europe's early modern pluralism.

\section{Bibliography}

Alles, Gregory D., Henning Graf Reventlow, Roland Gebauer, Niclas Förster, Johannes Wallmann, Bruce L. Guenther, Vincent Brümmer, et al., "Prayer », in Religion Past and Present Online, Brill, Leiden. Accessed June 7, 2019. doi: $<$ http://dx.doi.org/10.1163/1877-5888_rpp_COM_08151>.

Argyle, Michael, Psychology and Religion: An Introduction, Routledge, New York 2000.

Barnes, Corey, «Thomas Aquinas on Christ's Prayer », in Roy Hammerling (ed.), A History of Prayer: The First to the Fifteenth Century, Medieval Academy of America, Cambridge 2009, p. 319-336.

Bellah, Robert N., Philip E. Hammond, Varieties of Civil Religion, Harper and Row, San Francisco 1980.

Borris, Kenneth, "Platonism and Spenser's Poetic », in Kenneth Borris, Jon Quitslund, Carol Kaske (eds.), Spenser Studies XXIV, AMS Press, New York 2009, p. 209-269.

Bremmer, Jan N., Jan R. Veenstra (eds.), The Metamorphosis of Magic from Late Antiquity to the Early Modern Period, Peeters, Leuven 2002 (Groningen Studies in Cultural Change, 1).

Campanella, Tommaso, Le poesie, ed. Francesco Giancotti, Einaudi, Turin 1998.

- Selected Philosophical Poems of Tommaso Campanella: A Bilingual Edition, trans. Sherry Roush, University of Chicago Press, Chicago 2011.

Caravale, Giorgio, Forbidden Prayer: Church Censorship and Devotional Literature in Renaissance Italy, Ashgate, Burlington 2011.

Cave, Terence C., «Ronsard's Bacchic Poetry: From the Bacchanales to the Hymne De L'autonne », L'esprit créateur, 10/2 (1970), p. 104-116. 
Ceard, Jean, «Dieu, les hommes et le poète: structure, sens et fonction des mythes dans les Hymnes de Ronsard », in Madeleine Lazard (ed.), Autour des Hymnes de Ronsard: études, Champion, Paris 1984 (Unichamp, 7), p. 83-101.

Celenza, Christopher S., "Late Antiquity and Florentine Platonism: the 'PostPlotinian' Ficino ", in Michael J. B. Allen, Valery Rees and Martin Davies (eds.), Marsilio Ficino: His Theology, his Philosophy, his Legacy, Brill, Leiden 2002 (Brill's Studies in Intellectual History, 108), p. 71-98.

- "The Platonic Revival», in James Hankins (ed.), The Cambridge Companion to Renaissance Philosophy, Cambridge University Press, Cambridge 2007, p. 72-96.

- «What Counted as Philosophy in the Italian Renaissance », Critical Inquiry, 39/2 (2013), p. 367-401.

Cole, Allan Hugh Jr., « Prayer », in David Adams Leeming, Kathryn Wood Madden, Stanton Marlan (eds.), Encyclopedia of Psychology and Religion, Blanton Peale, New York 2009, p. 1371-1373.

Conti, Natale, Natale Conti's Mythologiae, trans. John Mulryan, Steven Brown, ACMRS, Tempe 2006 (Medieval and Renaissance Texts and Studies, 316).

Copenhaver, Brian P., «Renaissance Magic and Neoplatonic Philosophy: Ennead 4.3-5 in Ficino's De Vita Coelitus Comparanda ", in Gian Carlo Garfagnini (ed.), Marsilio Ficino e il ritorno di Platone, vol. II, Leo S. Olschki, Florence 1986 (Istituto nazionale di studi sul Rinascimento. Studi e testi, 15), p. 351-369.

- «Scholastic Philosophy and Renaissance Magic in the De Vita of Marsilio Ficino », Renaissance Quarterly, 37/4 (1984), p. 523-554.

De Capua, Paola, «Tra Giano Vitale, Pietro Corsi e Niccolò Ridolfi », Studi Medievali e Umanistici, 15 (2017), p. 451-512.

Di Nola, Tommaso, Tommaso Campanella. Il nuovo Prometeo da poeta-vate a restauratore della politica e del diritto, Edizioni Studio Domenicano, Bologna 1993.

Dillon, John M., Andrei Timotin (eds.), Platonic Theories of Prayer, Brill, Leiden 2016 (Studies in Platonism, Neoplatonism, and the Platonic Tradition, 19).

Erasmus of Rotterdam, The Correspondence of Erasmus (Letters 1356-1534), trans. Roger Aubrey Baskerville Mynors, Alexander Dalzell, Toronto University Press, Toronto 1992.

Faivre, Antoine, Access to Western Esotericism, State University of New York Press, Albany 1994.

Feinstein, Blossom, "On the Hymns of John Milton and Gian Francesco Pico », Comparative Literature, 20/3 (1968), p. 245-253. 
Ficino, Marsilio, Commentary on Plato's Symposium on Love, ed. and trans. Sears Reynolds Jane, Spring Publications, Dallas 1985.

- Three Books of Life, ed. and trans. Karol Kaske, John R. Clark, Medieval \& Renaissance Texts \& Studies, Tempe 1994.

- The Letters of Marsilio Ficino, vol. I, Shepeard-Walwin, London 2018.

Filoramo, Giovanni, «Religious Pluralism and Crises of Identity », Diogenes, 50/3 (2003), p. 31-44.

Foà, Simona, «Giraldi, Gregorio Lilio » in Dizionario Biografico degli Italiani, 56, Treccani, Rome 2001.

Ford, Philip, Ronsard's Hymnes: A Literary and Iconographical Study, Medieval \& Renaissance Texts \& Studies, Binghamton 1997.

Foucault, Michel, The Hermeneutics of the Subject, Lectures at the Collège de France (1981-1982), ed. Frédéric Gros, François Ewald, Alessandro Fontana, Graham Burche, Palgrave, New York 2005.

Friedman, John B., Orpheus in the Middle Ages, Harvard University Press, Cambridge 1970.

Garfagnini, Gian Carlo, Marsilio Ficino e il ritorno di Platone: studi e documenti, Leo S. Olschki, Florence 1986 (Istituto nazionale di studi sul Rinascimento. Studi e testi, 15).

Gersh, Stephen, "The Medieval Legacy from Ancient Platonism », in Stephen Gersh, Maarten J. F. M. Hoenen (eds.), The Platonic Tradition in the Middle Ages: a Doxographic Approach, De Gruyter, Berlin 2002, p. 3-30.

Goffis, Cesare F., «Il sincretismo lucreziano-platonico negli Hymni naturales del Marullo », Belfagor, 24 (1960), p. 386-417.

Gombrich, Ernst, «Icones Symbolicae: The Visual Image in Neo-Platonic Thought », Journal of the Warburg and Courtauld Institutes, 11 (1948), p. 163-192.

Hadot, Pierre, Arnold Ira Davidson, Philosophy as a Way of Life: Spiritual Exercises from Socrates to Foucault, trans. Arnold Ira Davidson, Blackwell, Oxford 2011.

Hadot, Pierre, The Veil of Isis: An Essay on the History of the Idea of Nature, trans. Michael Chase, Belknap Press of Harvard University Press, Cambridge 2006.

Hammerling, Roy, A History of Prayer: The First to the Fifteenth Century, Brill, Leiden 2008 (Brill's companions to the Christian tradition, 13).

Hanegraaff, Wouter J., Dictionary of Gnosis and Western Esotericism, Brill, Leiden 2006. 
- Esotericism and the Academy: Rejected Knowledge in Western Culture, Cambridge University Press, Cambridge 2012.

- «The Platonic Frenzies in Marsilio Ficino» in Jitse H. F. Dijkstra, Justin E. A. Kroesen, Yme Kuiper (eds.), Myths, Martyrs, and Modernity: Studies in the History of Religions in Honour of Jan N. Bremmer, Brill, Leiden 2010 (Numen Book Series: Studies in the History of Religions, 127), p. 553-567.

Hankins, James, «Ficino, Avicenna and the Occult Powers of the Rational Soul », in Fabrizio Meroi, Elisabetta Scapparone (eds.), La magia nell'Europa moderna: Tra antica sapienza e filosofia naturale, Leo S. Olschki, Florence 2003 (Istituto nazionale di studi sul Rinascimento. Atti di convegni, 23), vol. I, p. 35-52.

- « Marsilio Ficino and the Religion of the Philosophers », Rinascimento, 48 (2008), p. 101-121.

- Plato in the Italian Renaissance, Brill, Leiden 1990 (Columbia Studies in the Classical Tradition, 17).

- «Plato in the Middle Ages », in Joseph R. Strayer, William Chester Jordan (eds.), Dictionary of the Middle Ages, vol. IX, Scribner and Sons, New York 1987, p. 694-704.

Hornik, Henry, « More on Ronsard's Philosophy: The Hymns and Neoplatonism », Bibliothèque d'Humanisme et Renaissance, 27/2 (1965), p. 435-443.

Gersh, Stephen, Maarten J. F. M. Hoenen, Pieter Th. van Wingerden, The Platonic Tradition in the Middle Ages: A Doxographic Approach, De Gruyter, Berlin 2002.

Hill, Eugene D., «Everard Digby: A Syncretic Philosopher at Spenser's Cambridge », Kenneth Borris, Jon Quitslund, Carol Kaske (eds.), Spenser Studies XXIV, AMS Press, New York 2009, p. 135-154.

Hirai, Hiro, Le concept de semence dans les théories de la matière à la Renaissance. De Marsile Ficin à Pierre Gassendi, Brepols Publishers, Turnhout 2005 (De diversis artibus, 72).

James, William, The Varieties of Religious Experience: A Study in Human Nature, Modern Library, New York 1936.

Kippenberg, Hans G. and Kocku von Stuckrad, Einführung in die Religionswissenschaft, Beck, Munich 2003.

Klutstein, Ilana, Marsilio Ficino et la théologie ancienne: oracles chaldaïques, hymnes orphiques, hymnes de Proclus, Leo S. Olschki, Florence 1987 (Istituto nazionale di studi sul Rinascimento. Quaderni di Rinascimento, 5).

Kouidis, Apostolos P., « Ronsard's Four Hymns to the Seasons: A Glorification of the Benevolent World », Kentucky Romance Quarterly, 22/2 (1975), p. 223-234. 
Kristeller, Paul Oskar, Renaissance Thought and its Sources, Columbia University Press, New York 1979.

- Proclus as a Reader of Plato and Plotinus, and His Influence in the Middle Ages and in the Renaissance, Editions du C.N.R.S, Paris 1987.

Lazard, Madeleine, Autour des 'Hymnes' de Ronsard: études, Champion, Paris 1984 (Unichamp, 7).

Lazzarelli, Ludovico, Wouter J Hanegraaf, Ruud M. Bouthoorn, Lodovico Lazzarelli (1447-1500): The Hermetic Writings and Related Documents, Arizona Center for Medieval and Renaissance Studies, Tempe 2005.

Ludwig, Walther, « Antike Götter und christlicher Glaube. Die Hymni naturales von Marullo", in Berichte aus den Sitzungen der Joachim Jungius Gesellshaft der Wissenschaften E. V., Hamburg, Verlag Vandenhoeck \& Ruprecht, Hamburg 1992.

Marullus, Michael, Hymnes naturels, trans. Jacques Chomarat, Droz, Geneva 1995 (Travaux d'humanisme et Renaissance, 296).

- Inni naturali, trans. Donatella Coppini, Le Lettere, Firenze 1995 (Il nuovo melograno, 21).

- Poems, trans. Charles Fantazzi, Harvard University Press, Cambridge 2012.

Monfasani, John, "Platonic Paganism in the Fifteenth Century », in Cesare di Maio (ed.), Reconsidering the Renaissance, Center for Medieval and Early Renaissance Studies, New York 1992 (Medieval and Renaissance Texts and Studies, 93), p. 45-61.

Moreschini, Claudio, Rinascimento cristiano. Innovazioni e riforma religiosa nell'Italia del Quindicesimo e Sedicesimo secolo, Edizioni di Storia e Letteratura, Rome 2017.

Moss, Ann, «Latin Liturgical Hymns », Humanistica Lovaniensia: Journal of Neo-Latin Studies, 40 (1991), p. 73-111.

Pantin, Isabelle, La poésie du ciel en France dans la seconde moitié du seizième siècle, Droz, Geneva 1995 (Travaux d'humanisme et Renaissance, 297).

Piana, Marco, « Fallax Antiquitas: Gianfrancesco Pico Della Mirandola's Critique of Antiquity », Ph.D. Diss., McGill University 2018.

Pico della Mirandola, Gianfrancesco, Hymni heroici tres, Alexandrum Minutianum, Milan 1507.

- Ioannis Francisci Pici Mirandulae Domini, et Conc. Com. \&c. Hymni heroici decem post tres priores ad diuersos Coelites.: Item eiusdem principis poema eodem metro, quo excitamur a somno miserce uitee ad tranquillam, \& perpetuam uigiliam, Baptista Phaellus, Bologna 1531. 
Plotinus, Les Ennéades de Plotin: traduites pour la première fois en français accompagnées de sommaires, de notes et d'eclaircissements et précédées de la Vie de Plotin, trans. Marie Nicolas Buillet, Minerva, Frankfurt 1968.

- The Enneads, trans. Stephen Mackenna, Penguin, London 1991.

Proclus, Proclus' Hymns: Essays, Translations, Commentary, trans. Robert. M. van den Berg, Brill, Leiden 2001 (Philosophia antiqua: a Series of Monographs on Ancient Philosophy, 90).

Rappe, Sara, Reading Neoplatonism: Non-Discursive Thinking in the Texts of Plotinus, Proclus, and Damascius, Cambridge University Press, Cambridge 2007.

Rees, Valery, "A Sojourner in Florence: Neoplatonic Themes in the Hymni naturales of Marullus », Acta Conventus Neo-Latini, 16 (2018), p. 559-570.

- "Ficinian Ideas in the Poetry of Edmund Spenser » in Kenneth Borris, Jon Quitslund, Carol Kaske (eds.), Spenser Studies XXIV, AMS Press, New York 2009, p. 73-134.

Robichaud, Denis J.J., "Ficino on Force, Magic, and Prayers: Neoplatonic and Hermetic Influences in Ficino's Three Books on Life », Renaissance Quarterly / Publ. by the Renaissance Society of America (2017), p. 44-87.

Robichaud, Denis J. J., Matteo Soranzo, «Philosophical or Religious Conversion? Marsilio Ficino, Plotinus' Enneads and Neoplatonic epistrophe», in Simona Marchesini (ed.), Simple Twists of Faith, Changing Beliefs, Changing Faiths: People and Places, Alteritas, Verona 2017, p. 135-166.

Ronsard, Pierre, Hymnes, ed. Albert Py, Droz, Geneva 1978.

- Selected Poems, trans. Malcolm Quainton, Elizabeth Vinestock, Penguin, London 2002.

Rowan, Steven, Gerhild Scholz Williams, «Jacob Spiegel on Gianfrancesco Pico and Reuchlin: Poetry, Scholarship and Politics in Germany in 1512 », Bibliotheque d'humanisme et Renaissance 44, no. 2 (1982): 291-305.

Satterthwaite, Alfred W., Spenser, Ronsard, and Dubellay, Princeton University Press, Princeton, NJ, 2016.

Scaliger, Julius Caesar, Poetices libri septem, Jean Crespin, Geneva 1561.

Schilbrak, Kevin (ed.), Thinking Through Rituals: Philosophical Perspectives, Routledge, New York 2004.

Silver, Isidore, « Ronsard's Reflections on Cosmogony and Nature », PMLA, 79/3 (1964), p. 219-233. 
Soldati, Benedetto, La poesia astrologica nel Quattrocento: ricerche e studi, Le Lettere, Firenze 1986 [1906].

Soranzo, Matteo, «A New Look at Spirituality: Knowledge and Transformation in Early Modern Italy », Journal of Religion in Europe, 8 (2015), p. 185-209.

- "Concordance et Différence Religieuse », in L'époque de la Renaissance (14001600), t. II: La nouvelle culture (1480-1520), ed. Eva Kushner, Benjamins, Amsterdam 2017, p. 7-19.

- «Exploring the Forests of Antiquity: The Golden Bough and Early Modern Spirituality ", in Bill Gladhill, Micah Myers (eds.), Walking Through Elysium: Aeneid 6 and Its Cultural Reception, Toronto University Press, Toronto 2019, p. 77-93.

- «Les hymnes platoniciens et leur rôle dans la spiritualité prémoderne », in Eva Kushner (ed.), L'Époque de la Renaissance (1400-1600), t. II: La nouvelle culture (14801520), Benjamins, Amsterdam 2017, p. 29-37.

- Poetry and Identity in Quattrocento Naples, Ashgate, Farnham 2014.

- «Un'identità religiosa nel primo Cinquecento: gli Hymni Heroici Tres di Gianfrancesco Pico della Mirandola », Italian Studies, 70/1 (2015), p. 53-75.

- «Words of Conversion: Poetry and Religious Identity in Early Modern Italy », Journal of Religion in Europe, 6 (2013), p. 229-262.

Spenser, Edmund, The Fowre Hymnes, ed. Lilian Winstanley, Cambridge University Press, Cambridge 1907.

Stone, Donald, "The Sense and Significance of Ronsard's Seasonal Hymns ", Symposium: A Quarterly Journal in Modern Literatures, 18/4 (1964), p. 321-331.

Stuckrad, Kocku von, «Discursive Study of Religion: From States of the Mind to Communication and Action », Method and Theory in the Study of Religion, 15 (2003), p. 255-271.

- Locations of Knowledge in Medieval and Early Modern Europe: Esoteric Discourse and Western identities, Brill, Leiden 2010 (Brill's Studies in Intellectual History, 186).

- Scientification of Religion: An Historical Study of Discursive Change, 1800-2000, De Gruyter, Boston - Berlin 2014.

Tateo, Francesco, Tradizione e realtà nell'umanesimo italiano, Dedalo Libri, Bari 1969.

Timotin, Andrei, La prière dans la tradition platonicienne, de Plato à Proclus, Brepols, Turnhout 2017 (Recherches sur les rhétoriques religieuses, 22).

Stark, Rodney, Roger Finke, Acts of Faith: Explaining the Human Side of Religion, University of California Press, Berkeley 2000. 
Voss, Angela, Marsilio Ficino, North Atlantic Books, Berkeley 2006.

Walker, Daniel P., «Orpheus the Theologian and Renaissance Platonists », Journal of the Warburg and Courtauld Institutes, 16/1-2 (1953), p. 100-120.

- Spiritual and Demonic Magic from Ficino to Campanella, University of Notre Dame Press, Notre Dame 1975.

Yates, Frances A., Giordano Bruno and the Hermetic Tradition, University of Chicago Press, Chicago - London 1964.

- The Occult Philosophy in the Elizabethan Age, Routledge, London 1979. 